WILLEM H. BUITER

London School of Economics

and National Bureau of Economic Research

MARCUS H. MILLER

University of Warwick and Princeton University

\title{
Changing the Rules: Economic Consequences of the Thatcher Regime
}

MORE THAN FOUR YEARS have passed since Margaret Thatcher took office as prime minister in June 1979; and with the election of June 1983, she has been given the second term that she always said would be necessary to put into effect the changes she planned for the British economy. There can be little doubt that the steps taken thus far in the "return to sound money" have marked a significant turning point in macroeconomic policymaking in the United Kingdom. There have been changes in the objectives toward which policy is ultimately directed, changes in how the instruments of policy are used in practice, and a shift in the strategic relation between the government and organized labor.

The 1944 White Paper, similar in spirit to the U.S. Employment Act of 1946, was interpreted by most postwar governments of the United Kingdom as a commitment to use the policy instruments at their disposal to pursue high employment, low inflation, economic growth, and a sustainable external balance. Actual performance fell far short of such plans, and inflation in particular proved an increasingly severe problem

We are grateful for constructive suggestions from members of the Brookings Panel that have much improved the paper. We would also like to thank Avinash Dixit, Paul Fisher, Brian Henry, Richard Layard, and Stephen Nickell, without implying that they accept our conclusions. The views expressed are those of the authors and not necessarily those of the National Bureau of Economic Research. 
in the late 1960s and 1970s. Observing perhaps that the reach of government was exceeding its grasp, Prime Minister Thatcher has abandoned the commitment to full employment and has not sought to influence wages and prices by an explicit incomes policy. In pursuit of objectives that include the reduction of inflation as a first priority (together with the creation of conditions for a resumption of sustainable growth) "intermediate financial targets" are now established and announced for years in advance, and in practice policy is from day to day directed at achieving these intermediate targets.

What explains these changes in macroeconomic policymaking, in our interpretation of events, is the apparent desire to achieve a major shift in the strategic relation between the government and the private sector, organized labor in particular. The 1944 White Paper, conceived toward the end of a major war and after the experience of a prolonged depression, effectively established rules for conducting official policies; the policies, given appropriate support from the "social partners" in the private sector, were designed to extend the cooperative spirit of the World War II economy and avoid the economic failures of the 1930s. Such a cooperative equilibrium tends to be inherently fragile, however, as each party may be tempted to depart from the rules in pursuit of its own private advantage.

With the passage of time, indeed, the incentive to cooperate seems to have diminished. Governments have been accused of manipulating the economy for short-term electoral advantage, for example. ${ }^{1}$ And unions have increasingly been inclined to take employment for granted, push wages ahead of productivity, and resist the introduction of new technology and work practices. After the downfall of prime ministers Edward Heath and James Callaghan, who struggled to contain the pressure of rising wages while stabilizing the economy at a high level of employment, it appears that Margaret Thatcher has decided to restructure the framework within which public and private decisionmakers operate. The government no longer accepts responsibility for high employment, or indeed for any ultimate objective other than inflation; it no longer seeks to develop cooperation with the social partners that have heretofore played a crucial role (the Trades Union Congress and the Confederation

1. See William D. Nordhaus, "The Political Business Cycle," Review of Economic Studies, vol. 42 (April 1975), pp. 169-90. 
of British Industry, in particular). The unilateral announcement of unconditional intermediate targets for policy is a signal of the strategic shift that we believe the Thatcher experiment is designed to achieve.

In what follows we present a profile of recent economic developments in the United Kingdom and review monetary and fiscal policy and the evolution of taxes and spending under the medium-term financial strategy (MTFS). We then turn to consider three central issues. First, howif at all-have changes in policy affected the costs of reducing inflation? Second, has there been a productivity breakthrough? And third, does the rejection of a policy of passive accommodation require the government to abandon stabilization policy?

\section{Profile of the Recession}

The dominant consequences of macroeconomic policy in the economy of the United Kingdom during the past two years are a continued decline of real economic activity during the first half of 1981 followed by a slow resumption of economic growth in the second half of that year, a steady fall in employment and rise in unemployment, and a significant reduction in the rate of inflation. In 1983 unemployment peaked and inflation "bottomed out" while the recovery of output continued at a rate of 2.6 percent a year (based on the compromise estimate of GDP in the two years since the first half of 1981). For a sustained recoverythat is, a significant and lasting reduction in the gap between actual and potential output - economic growth must remain above the growth of potential for some time. Prospects for this are poor given current and announced future policy and the likely development of world economic activity.

As shown in figure 1, striking parallels can be seen between the behavior of GDP, manufacturing output, and unemployment of the Great Depression and that of the depression of recent years. A continuation of these similarities for the years to come would be most welcome; real GDP growth averaged 4.7 percent during the five years following 1932 and unemployment declined from a peak of 15.6 percent in 1932 to 7.8 percent in 1937. We argue below, however, that the prospects for such a recovery are not good. It is therefore likely that, by most of the usual criteria (output growth, employment growth, unemployment rates), the 
Figure 1. Comparison between 1925-35 and 1975-83, United Kingdom, Selected Indicators
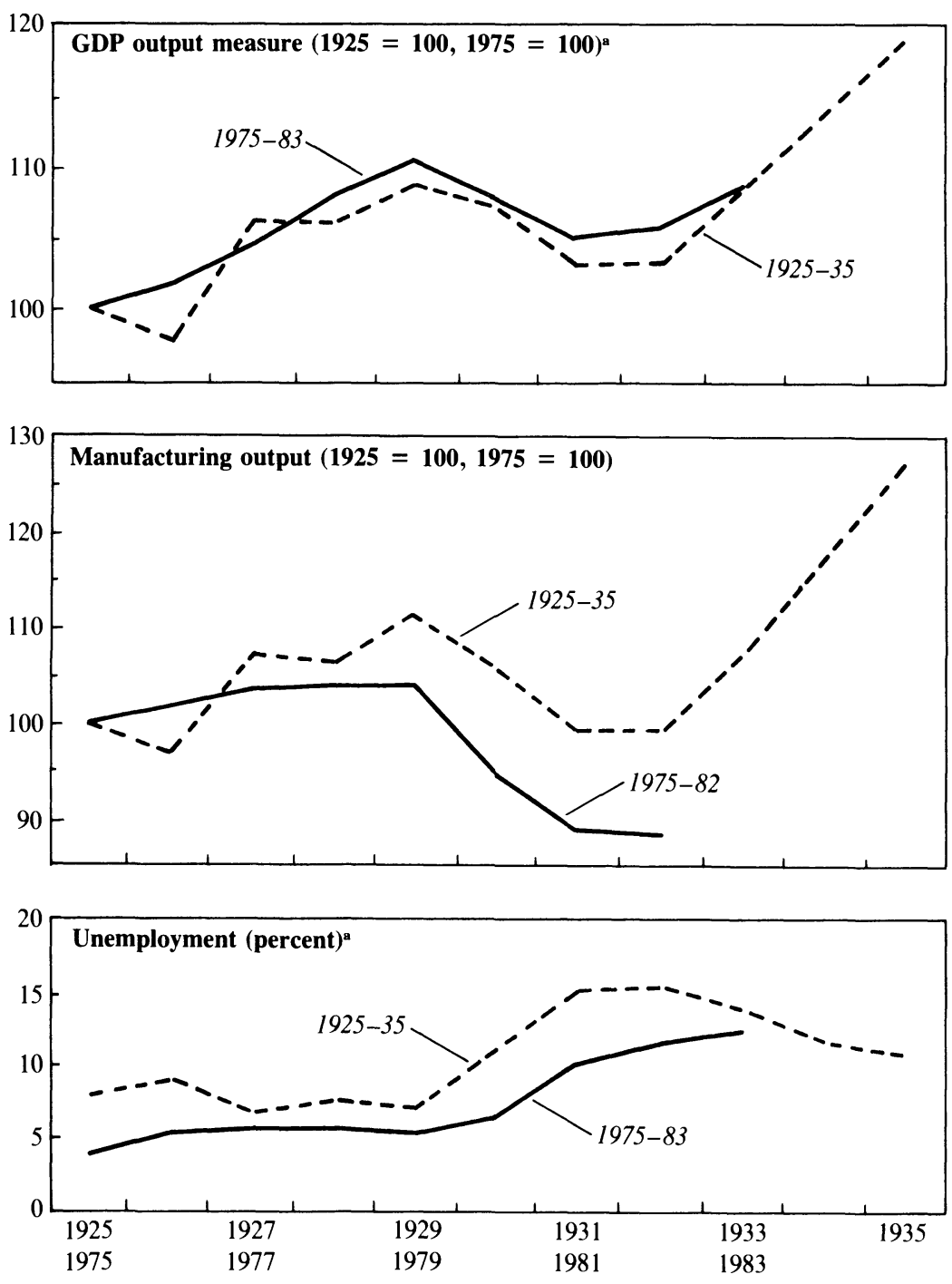

Sources: Authors' updating of figure appearing in National Institute Economic Review, no. 95 (February 1981), p. 7. Data for 1925-35 are from C. H. Feinstein, National Income, Expenditure and Output of the United Kingdom, 1855-1965, Studies in the National Income and Expenditure of the United Kingdom 6 (Cambridge University Press, 1972), tables 6, 51, 57, pp. T19, T112, T126. Data for 1975-82 are from United Kingdom, Central Statistical Office, Economic Trends, no. 358 (August 1983), pp. 6, 28, 36. GDP and unemployment for 1983 are estimates.

a. The estimate of 108.5 for GDP output measure for 1983 is from National Institute Economic Review, no. 105 (August 1983), p. 7; the estimate of 12.5 for the 1983 unemployment rate is the simple average of the first nine months of that year and is from Economic Trends, no. 360 (October 1983), p. 36. 
depression of the 1980s will turn out to be worse than the Great Depression of the 1930s. The impact of the recent depression in terms of absolute material deprivation is less severe, on average, because of the much higher real income base in 1980 and the higher real value of unemployment compensation.

The United Kingdom has not been alone in experiencing high inflation and rising unemployment over the last decade, as can be seen in figure 2 , which also includes the average performance of the seven largest OECD economies. The burst of inflation and the associated rise in unemployment from 1973 to 1978 following the first oil-price increase are clearly in evidence, with the United Kingdom showing an exaggerated response. The average unemployment and inflation rates during the preceding decade are included for purposes of comparison.

After 1978 and the second oil-price rise there was another burst of inflation that has subsided; inflation is now close to what it was on average before the oil shocks. Once again, the response of the United Kingdom has been exaggerated, with a bigger surge of inflation and a sharper increase in unemployment.

Economic performance of the rest of the industrial world continued to worsen during 1981 and 1982. Although the behavior of the unemployment and inflation rates in the United Kingdom and in the nations of the Organization for Economic Cooperation and Development as a whole (figure 2) suggests a continued relative worsening of the United Kingdom's cyclical position, output in 1982 and 1983 seems to indicate improvement in that position vis à vis its industrial partners. Figure 3 shows the comparative behavior of GNP for the United Kingdom and the OECD relative to crude trend paths that are extrapolations of the peak-to-peak growth achieved between 1973 and 1979 (2.7 percent for the OECD and 1.4 percent for the United Kingdom). Although the annual observations suggest that the United Kingdom has simply resumed this low trend growth in the past two years, the half-year points indicate a more promising rate of recovery-2.6 percent a year. Reasons for why unemployment in the United Kingdom is so high given its path of output are explored below.

The external conditions faced by the economy of the United Kingdom between 1981 and 1983 have been almost uniformly unfavorable. World trade-total and manufacturing-declined in 1982, reflecting the stagnant real output in the industrial countries just described. World real interest 
Figure 2. Unemployment and Inflation, United Kingdom and the OECD, 1973-83a

Inflation (percent)

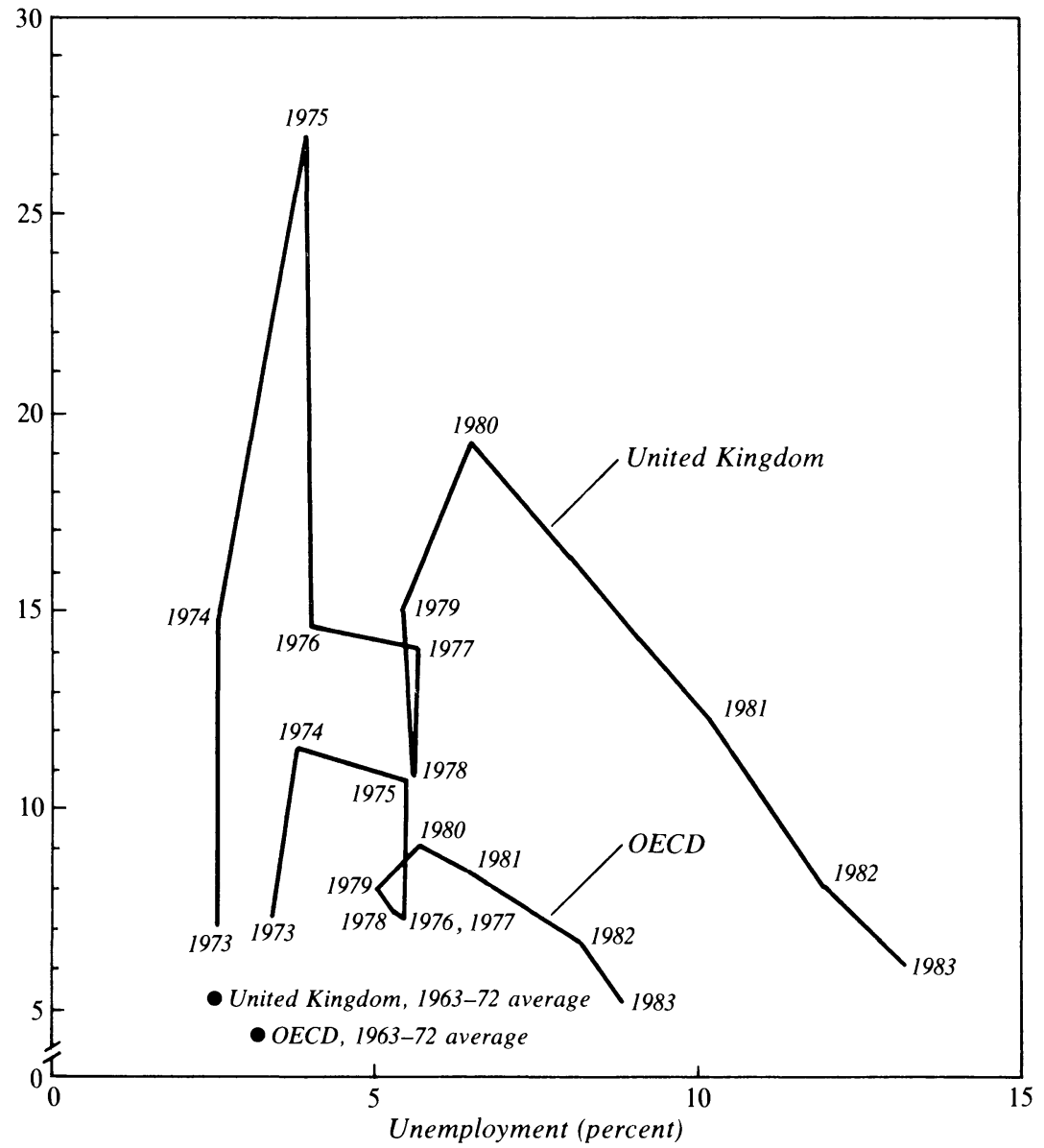

Source: International Monetary Fund, World Economic Outlook (IMF, 1983), pp. 170, 174.

a. The OECD curve is based on data for the seven largest countries. Inflation is measured as the rate of change in the GDP (market prices) deflator for the United Kingdom, France, and Italy, and by the rate of change of the GNP deflator for the other four countries.

rates remained high at 3 to 4 percent, as nominal interest rates and inflation declined at a similar rate. Unlike most industrial countries, the decline in the real price of oil is a mixed blessing for the United Kingdom, which by now is a sizable net exporter of oil. Growth of the world economy is unlikely to provide a strongly expanding source of demand for output from the United Kingdom in the next few years. The very 
Figure 3. Real Gross Product in the United Kingdom and the OECD, 1973-82 a

Real gross product $(G P)$ index, $1973=100(\log$ scale $)$

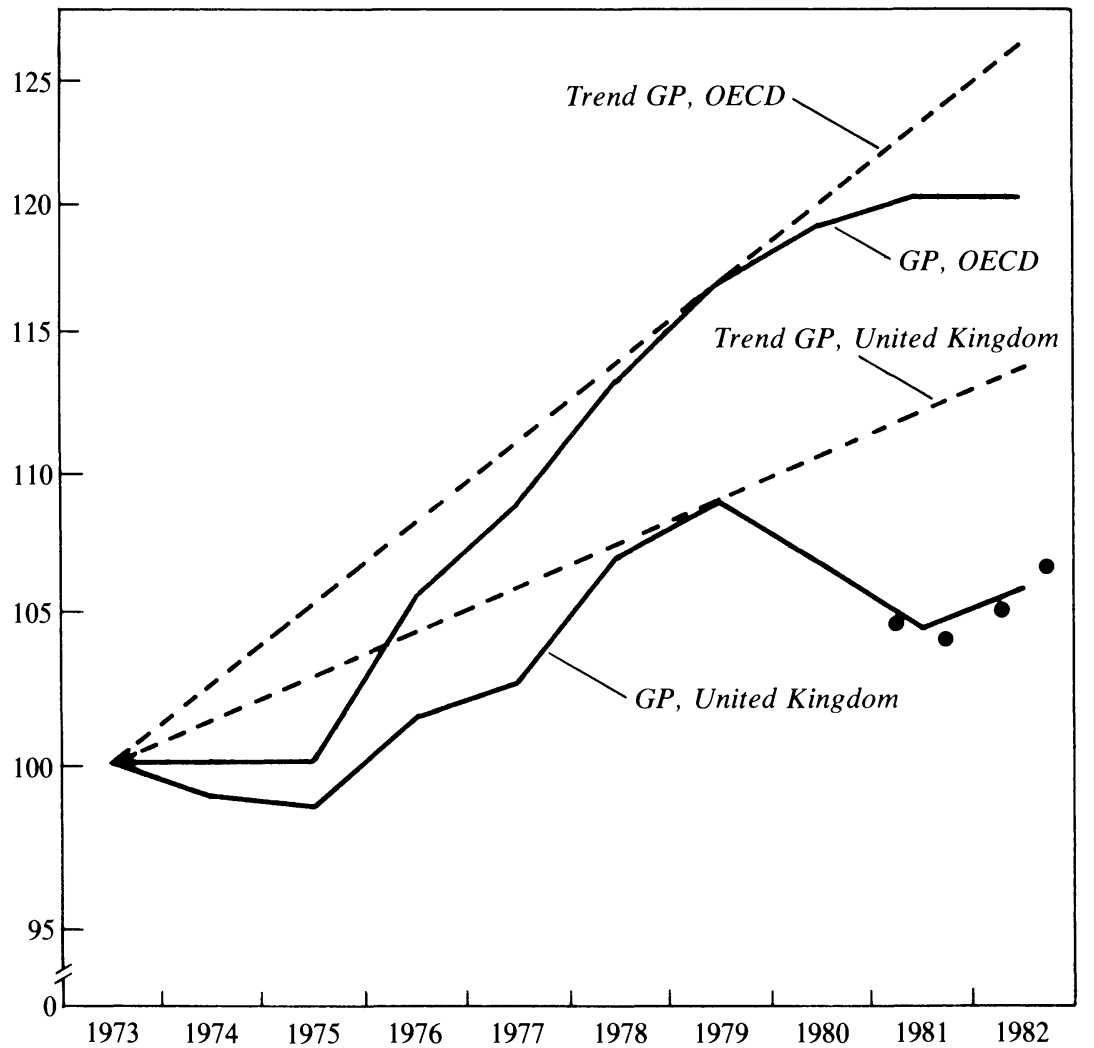

Source: National Institute Economic Review, no. 105 (August 1983), table 22.

a. Figures for the United Kingdom are for GDP on the expenditure basis at constant market prices. Dots indicate data on a half-yearly basis for 1981-82.

rapid expansion of the U.S. economy, welcome as it is, may not continue; and even if it does, the United States now accounts for just under 20 percent of total OECD imports and exports.

\section{Monetary Policy}

In the design of its counterinflationary medium-term financial strategy, or MTFS, the government had given pride of place to the attainment of restrictive target growth rates for sterling M3 (denoted £M3 here, a 
broadly defined domestic monetary aggregate that excludes foreign currency holdings by residents) over a four-year period. As is apparent from figure 4 and table 1 , the chosen aggregate has tended to overshoot these targets and has grown persistently faster than the other major monetary aggregates, which are also shown. However, as the figure indicates, this overshooting of the target range has largely been accommodated ex post by upward shifts in the base-point from which subsequent $£ M 3$ growth ranges apply.

This evidence raises two obvious questions: Was money tight after all? How credible is the stance of anti-inflationary policy based on such an aggregate?

\section{MONEY SUPPLY AND INTEREST RATES}

Annual financial statements and budget reports published by the House of Commons Treasury and Civil Service Committee (hereafter Treasury Committee) conclude that monetary policy has been restrictive since the introduction of the MTFS, a view essentially supported by the former governor of the Bank of England. Those who take such a view must, however, discount the behavior of the chosen monetary aggregate. ${ }^{2}$

In presenting the official view at a recent conference on monetary targeting, John Fforde listed a number of special factors (including the cyclical flow of funds, changes in saving behavior in the private sector and in patterns of corporate finance, and structural changes in the financial system). These, it is argued, have rendered $£ M 3$ a poor indicator of the stance of monetary policy. ${ }^{3}$ On an earlier occasion, Jürg Niehans described it as a "distorting mirror" and contended that the behavior of the monetary base would provide a better guide. ${ }^{4}$ Table 1 shows that the average growth rate of the base since 1980 was only one-fourth of that for £M3.

It is now evident that even in the first year of the MTFS the official

2. Lord Richardson, "British Economic Policy over the Last Decade," Bank of England Quarterly Bulletin, vol. 23 (June 1983), pp. 194-99.

3. J. S. Fforde, "Setting Monetary Objectives," Bank of England Quarterly Bulletin, vol. 23 (June 1983), pp. 200-08.

4. Jürg Niehans, "The Appreciation of Sterling-Causes, Effects, and Policies," SSRC Money Study Group Discussion Paper(New York: Social Science Research Council, 1981). 
Figure 4. Money Stock and Liquidity, Target Growth Rates and Actuals, United Kingdom, 1979-83a

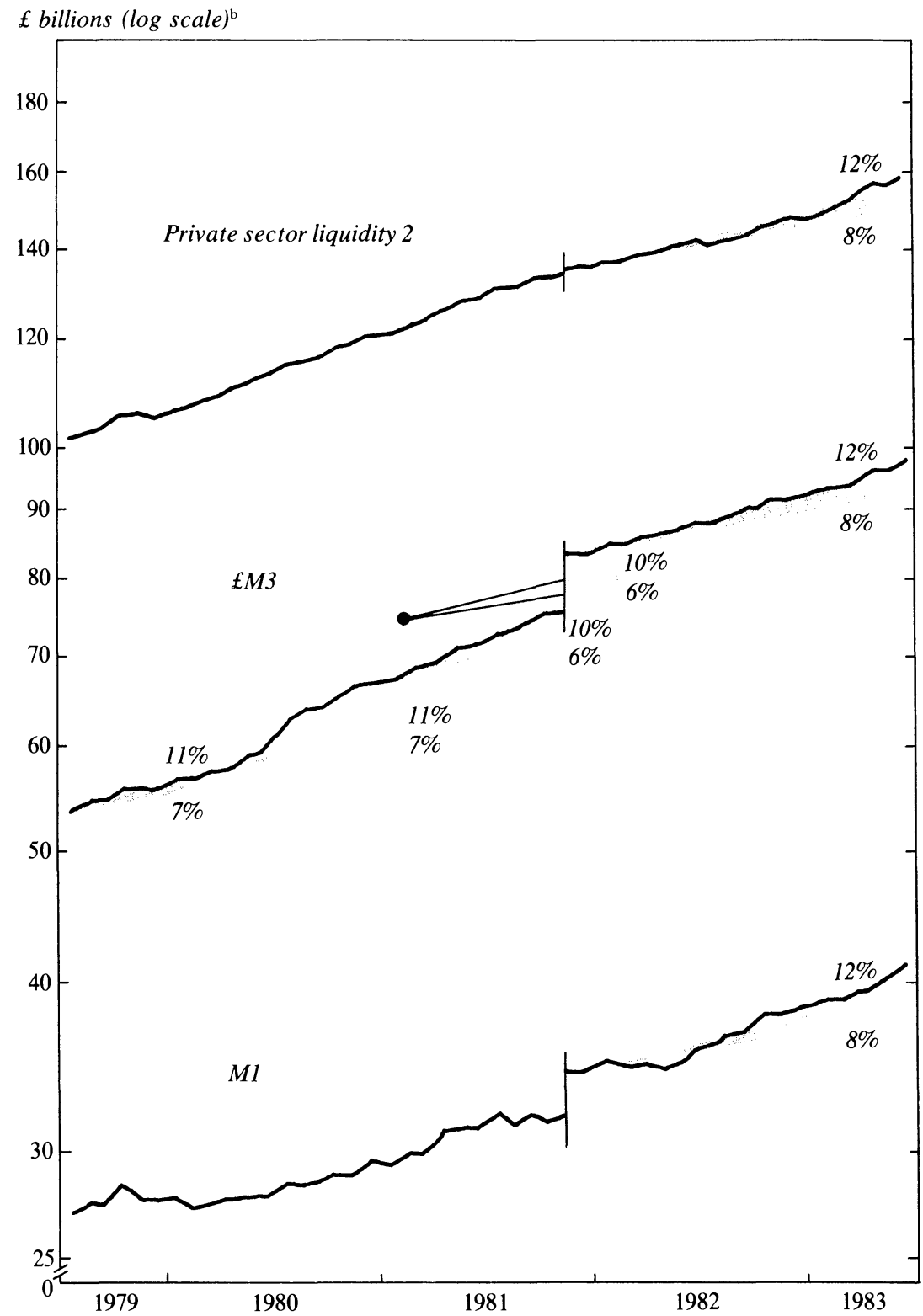

Source: Economic Trends, no. 360 (October 1983), p. 53, and previous issues.

a. Seasonally adjusted data. The break in the $£ \mathrm{M} 3$ series reflects the redefinition of the monetary sector in midNovember 1981. The large dot indicates the base for £M3 target range after this change. See definitions of monetary aggregates in table 1 , note a.

b. Successive target ranges are shown as annual growth rates. 


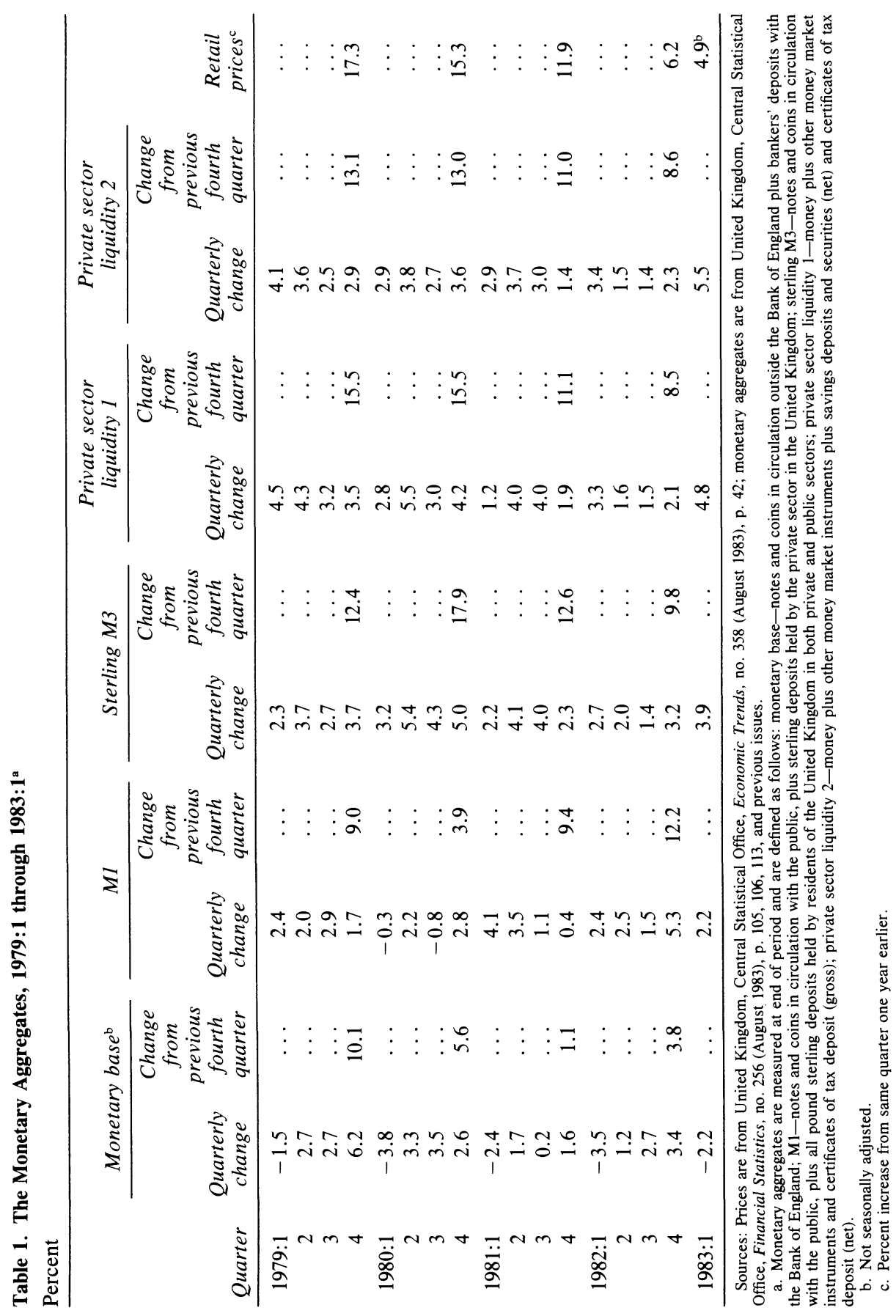


Table 2. Interest Rates and Inflation, 1975 through 1983:1

\begin{tabular}{|c|c|c|c|c|c|c|}
\hline \multirow[b]{3}{*}{$\begin{array}{l}\text { Year or } \\
\text { quarter }\end{array}$} & \multirow{3}{*}{$\begin{array}{l}\text { Bank of } \\
\text { England's } \\
\text { minimum } \\
\text { lending } \\
\text { rate } \\
\text { (bank }^{\text {rate) }}\end{array}$} & \multicolumn{3}{|c|}{ Interest rates (percent per year) } & \multirow{2}{*}{\multicolumn{2}{|c|}{$\begin{array}{c}\text { Inflation rates (percen } \\
\text { change from one year } \\
\text { earlier) }\end{array}$}} \\
\hline & & \multirow[b]{2}{*}{$\begin{array}{l}\text { Treasury } \\
\text { bill } \\
\text { discount }^{\text {rate }}\end{array}$} & \multirow[b]{2}{*}{$\begin{array}{l}\text { Euro- } \\
\text { dollar } \\
\text { three- } \\
\text { month } \\
\text { rate }^{\mathrm{b}}\end{array}$} & \multirow{2}{*}{$\begin{array}{c}\text { Yield on } \\
\text { twenty- } \\
\text { year } \\
\text { British } \\
\text { govern- } \\
\text { ment se- } \\
\text { curities }^{c}\end{array}$} & & \\
\hline & & & & & $\begin{array}{l}\text { Retail } \\
\text { price } \\
\text { index }^{\mathrm{b}}\end{array}$ & $\begin{array}{c}\text { GDP } \\
\text { deflator } \\
\text { at factor } \\
\text { cost }\end{array}$ \\
\hline 1975 & 11.00 & 10.64 & 5.87 & 14.39 & 24.9 & 27.2 \\
\hline 1976 & 14.00 & 13.51 & 5.06 & 14.43 & 15.1 & 14.1 \\
\hline 1977 & 7.62 & 6.29 & 7.19 & 12.73 & 12.1 & 12.3 \\
\hline 1978 & 12.50 & 11.56 & 11.69 & 12.47 & 8.4 & 11.5 \\
\hline 1979 & 17.00 & 15.84 & 14.50 & 12.99 & 19.8 & 13.4 \\
\hline 1980 & 14.00 & 13.13 & 17.75 & 13.79 & 15.1 & 18.8 \\
\hline 1981 & 14.50 & 14.62 & 13.75 & 14.75 & 12.0 & 10.7 \\
\hline 1982 & 10.25 & 9.72 & 9.25 & 12.88 & 5.4 & 7.0 \\
\hline 1980:1 & 17.00 & 16.28 & 19.94 & 14.44 & 19.8 & 18.0 \\
\hline 2 & 17.00 & 15.68 & 9.75 & 14.02 & 21.0 & 19.8 \\
\hline 3 & 16.00 & 14.33 & 13.94 & 13.34 & 15.9 & 20.1 \\
\hline 4 & 14.00 & 13.13 & 17.75 & 13.34 & 15.1 & 17.7 \\
\hline 1981:1 & 12.00 & 11.53 & 14.88 & 13.84 & 12.6 & 15.2 \\
\hline 2 & 12.00 & 11.88 & 17.69 & 14.17 & 11.3 & 11.5 \\
\hline 3 & 14.00 & 15.12 & 17.88 & 15.27 & 11.4 & 9.4 \\
\hline 4 & 14.50 & 14.62 & 13.75 & 15.68 & 12.0 & 7.2 \\
\hline 1982:1 & 13.00 & 12.51 & 15.47 & 14.68 & 10.4 & 5.6 \\
\hline 2 & 12.50 & 12.27 & 15.66 & 13.73 & 9.2 & 7.8 \\
\hline 3 & 10.50 & 9.97 & 11.50 & 12.28 & 7.3 & 6.5 \\
\hline 4 & 10.25 & 9.72 & 9.25 & 10.83 & 5.4 & 7.8 \\
\hline 1983:1 & 10.50 & 10.23 & 9.69 & 11.37 & 4.6 & 7.8 \\
\hline
\end{tabular}

Sources: Bank rate (minimum lending rate) and Treasury bill discount rate are from National Institute Economic Review, no. 103 (February 1983), table 13, p. 79, and previous issues. Other rates and price indexes are from Economic Trends, no. 358 (August 1983), pp. 6, 42, 66, and previous issues.

a. Last Friday of the period.

b. Last month of the period.

c. Average of working days.

assessment of financial conditions was not based on the behavior of £M3 relative to the target. Twice in 1980 and again in March 1981 short-term interest rates were lowered (see table 2) while $£ \mathrm{M} 3$ was well above its target range. "On each occasion," John Fforde writes, "it had to be judged that the performance of $\mathbf{M}_{3}$ required interpretation in the light of other indicators, including the exchange rate, and that the thrust of policy was in practice as restrictive as had been intended."'s

5. Fforde, "Setting Monetary Objectives," p. 205. 
During the next financial year, 1981-82, when £M3 again overshot its target growth path, the Treasury nevertheless concluded that "as intended, financial conditions have been moderately restrictive," and cited as evidence the narrow aggregates, the exchange rate, asset prices, real interest rates, and nominal GDP. ${ }^{6}$

In the 1982-83 financial year (for which growth ranges of 8 to 10 percent had been targeted for $£ \mathrm{M} 3$ and two other monetary aggregates in addition) success in targeting was achieved partly because of an increase of 2 percentage points in interest rates when the pound sterling weakened sharply in November $1982 .{ }^{7}$ In 1983 , with the pound recovering once again, monetary aggregates appear likely to exceed their target ranges.

Also shown in table 2 are short-term interest rates, Eurodollar rates, and the domestic inflation rate. Although interest rates have been historically high under current policy, they were evidently overtaken by Eurodollar rates in 1981. Furthermore, for much of the period, and especially 1980 , interest rates do not seem very high when compared with inflation as measured by the annual rate of change of the GDP deflator.

Before concluding that short-term pretax real rates were low or negative, it is worth noting that simply subtracting the increase of a price index over the past year from the current three-month nominal rate, as is the conventional practice, may not provide a good measure of the ex ante short-term real rate. In a recent publication that made use of inflation expectations from contemporary private sector forecasts, the pretax short-term real rate for private borrowers is shown to be positive in 1980 and 1981 as well as 1982, averaging roughly 3, 4, and 6 percent in the respective years. ${ }^{8}$ The evidence of long-term real rates (available in the market since March 1981, thanks to the issue of indexed government debt) suggests a stable market forecast of long-run real rates lying between 2 and 3 percent, which is not much affected by swings in shortterm real rates.

6. Financial Statement and Budget Report, 1982-83 (London: Her Majesty's Stationery Office, 1983), p. 14.

7. The base rate rose from 9 percent in early November to a high of 11 percent at the beginning of 1983. See Bank of England Quarterly Bulletin, vol. 23 (March 1983), p. 23.

8. "Real Interest Rates," Bank of England Quarterly Bulletin, vol. 22 (December 1982), p. 483. 
MONETARY POLICY AND THE EXCHANGE RATE

The recent history of nominal and real exchange rates in the United Kingdom is shown in table 3. ${ }^{9}$ For nominal rates the pattern since 1979 has been one of an appreciation followed by a greater subsequent depreciation. The average effective rate of the pound sterling, using the International Monetary Fund weights, rose 10 percent from 1979 to 1981 , then fell 5 percent in 1982. Against the U.S. dollar alone the pound sterling rose by 10 percent in 1980 but declined by 25 percent over the next two years. By 1983:2 the pound had further declined against these 1982 averages, by 7.1 percent on the effective rate and by 11.1 percent against the dollar.

Given the relatively high rates of inflation in the United Kingdom over this period, the overall nominal depreciation is not reflected in the real exchange rate. Relative wholesale prices rose by 16 percent from their 1979 average by 1981 , fell only a few percentage points in the next year, and stood about 9 percent higher in 1983:2 than in 1979. There was substantially greater real appreciation, as measured by unit-labor costs: based on the latest figures in table 3, these stood between 11 and 21 percent above their 1979 levels (using actual and normalized costs, respectively).

We offer no complete explanation of the behavior of the nominal and real exchange rates in the United Kingdom since 1979; indeed, we find the decline in competitiveness puzzling. The capital market equilibrium relation among the nominal exchange rate (or the domestic currency price of foreign spot exchange), $e$, the risk premium, $\epsilon$, the domestic nominal interest rate, $r$, and the foreign nominal interest rate, $r^{*}$, can be expressed as ${ }^{10}$

$$
E_{t} \dot{e}(t)=r(t)-r^{*}(t)-\epsilon(t)
$$

or

$$
e(t)=\bar{e}(t)+\int_{t}^{\infty} E_{t}\left[r^{*}(s)-r(s)\right] d s+\int_{t}^{\infty} E_{t} \epsilon(s) d s .
$$

9. In table 3 the nominal exchange rate is defined, according to convention in the United Kingdom, as the foreign currency price of domestic currency, and the real rate is defined accordingly. In equation 1 here and equation 2 below, however, the exchange rate is defined according to the convention in the United States.

10. The expectation operator, $E_{t}$, is conditional on the information available at time $t$. Dots on variables indicate their rates of change. 


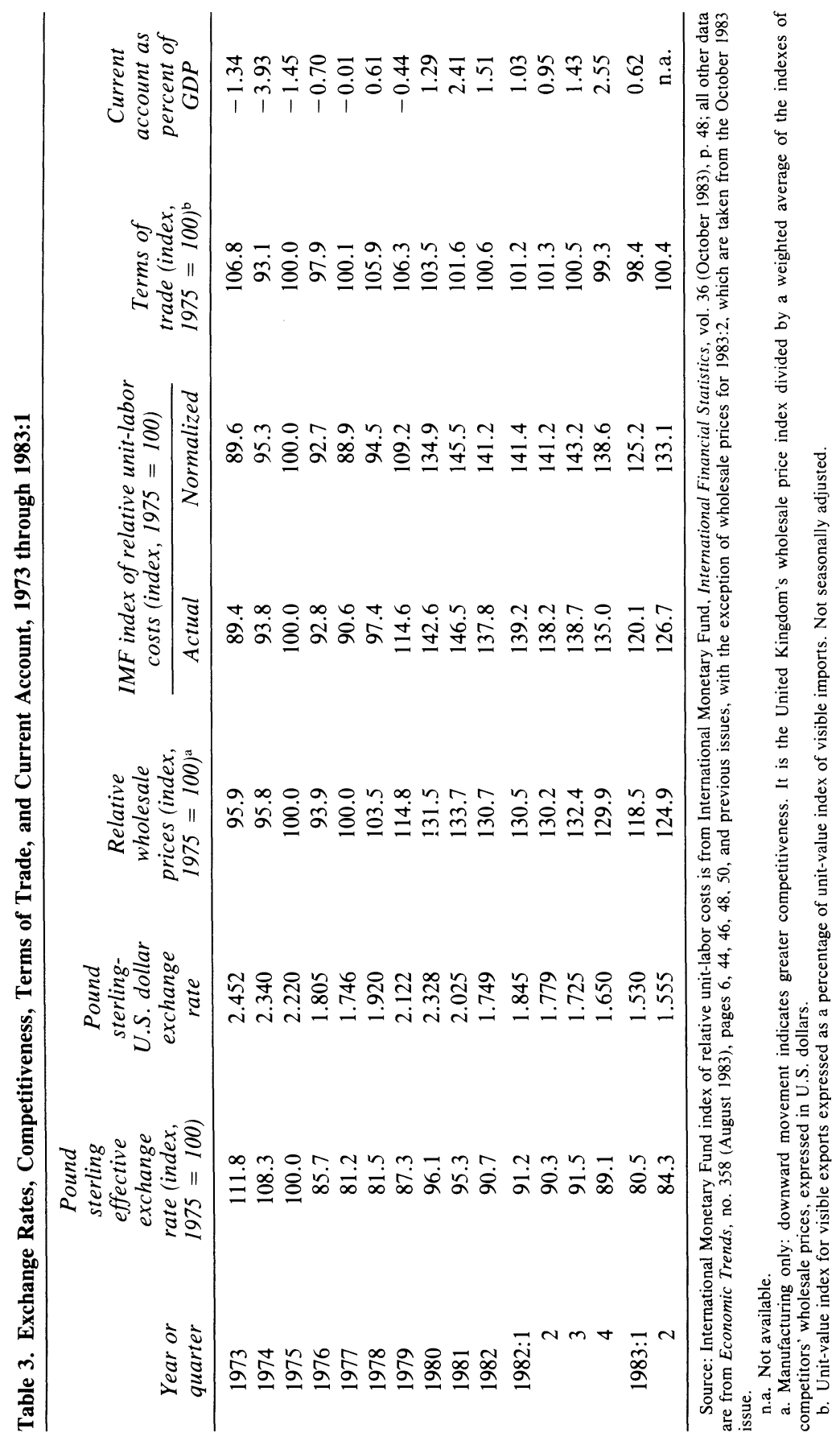


The current nominal exchange rate equals its long-run equilibrium value, $\bar{e}(t)$, plus the integral of all future expected foreign-domestic nominal interest rate differentials, plus a residual that can be interpreted as the integral of all expected future risk premiums.

Next, defining $c \equiv e+p^{*}-p$ as a measure of international price competitiveness, where $p$ and $p^{*}$ are appropriate domestic and foreign price indexes, we derive

$$
E_{t} \dot{c}(t)=r(t)-E_{t} \dot{p}(t)-\left[r^{*}(t)-E_{t} \dot{p}^{*}(t)\right]-\epsilon(t)
$$

or

$$
\begin{aligned}
c(t)= & \bar{c}(t)+\int_{t}^{\infty} E_{t}\left[r^{*}(s)-\dot{p}^{*}(s)-r(s)+\dot{p}(s)\right] d s \\
& +\int_{t}^{\infty} E_{t} \epsilon(s) d s .
\end{aligned}
$$

The current real exchange rate equals its long-run equilibrium values, $\bar{c}$, plus the integral of all future expected foreign-domestic real interest rate differentials, plus the integral of all future expected exchange risk premiums. ${ }^{11}$

Forsyth and Kay, as well as others, view much of the loss of competitiveness since 1979 as the equilibrium response to such real shocks as the growth of oil production in the North Sea and the increase in the price of oil during OPEC II and attribute a large part of the decline in $c(t)$ to a decline in $\bar{c}(t)$. We see no reason to revise our earlier conclusion that the effect of North Sea oil on competitiveness was relatively minor, with a loss of 10 percent a reasonable upper bound..$^{12}$

Overshooting theories, such as those proposed by Rudiger Dornbusch, emphasize tight money and its effect on current and anticipated future real interest rate differentials. Monetary growth deceleration and other anti-inflationary measures are assumed not to affect long-run competitiveness, $\bar{c}$. It is always possible to make this approach consistent with the facts by postulating arbitrary paths for the unobservable anticipated future real interest rate differentials. To "explain" a sudden

11. Note that $\bar{e}$ and $\bar{c}$ can only change unexpectedly.

12. The low estimate of Forsyth and Kay was 8.2 percent. See J. P. Forsyth and J. A. Kay, "The Economic Implications of North Sea Oil Revenues," Working Paper 10 (London: Institute for Fiscal Studies, 1980). Our earlier conclusion was presented in Willem H. Buiter and Marcus Miller, "The Thatcher Experiment: The First Two Years," BPEA, 2:1981, pp. 315-79. 
Table 4. Short-run Real Interest Rates, 1979:1 through 1982:4a

Percent

\begin{tabular}{rccc}
\hline & Real rate & $\begin{array}{c}\text { World real } \\
\text { in the } \\
\text { rate minus } \\
\text { United } \\
\text { Kingdom's } \\
\text { Weal rate }\end{array}$ \\
\hline $1979: 1$ & -0.29 & 1.24 & -1.53 \\
2 & 0.65 & 0.73 & -0.08 \\
3 & 2.07 & -0.53 & 2.60 \\
4 & 3.74 & -0.76 & 4.50 \\
$1980: 1$ & 4.65 & -1.72 & 6.37 \\
2 & 3.35 & -4.12 & 7.47 \\
3 & 1.98 & -5.77 & 7.75 \\
4 & 3.31 & -4.57 & 7.88 \\
$1981: 1$ & 3.63 & -3.67 & 7.30 \\
2 & 5.57 & 0.38 & 5.19 \\
3 & 6.28 & 5.72 & 0.56 \\
4 & 4.25 & 7.42 & -3.17 \\
$1982: 1$ & 4.39 & 6.91 & -2.52 \\
2 & 4.47 & 4.47 & 0.00 \\
3 & 3.43 & 3.47 & -0.04 \\
4 & 3.42 & 1.92 & 1.50 \\
\hline
\end{tabular}

Sources: Nominal interest rates for all countries except the United Kingdom are from International Monetary Fund, International Financial Statistics, various issues; the GDP deflators are from Organization for Economic Cooperation and Development, Main Economic Indicators, various issues. Data for the United Kingdom are from table 2.

a. The world interest rate was calculated as a weighted average of the rates of the United States, Germany, Japan, and France, with the following weights: United States, 0.392; Germany, 0.225; Japan, 0.225; and France, 0.165. Nominal interest rates are the three-month Treasury bill rate for the United States and the United Kingdom and the call rates for the other countries. Real rates are the nominal rates minus the change in the GDP deflator over the last four quarters.

and unexpected 16 percent loss of competitiveness this way would require an increase of 4 percent in expected real interest rates in the United Kingdom relative to those in the rest of the world beginning in 1979 and remaining 4 percent for four years.

Although competitiveness measured by relative wholesale prices declined by 16 percent between 1979 and 1981, table 4 indicates that cumulative ex post real interest rates between 1980 and 1982 were higher overseas than in the United Kingdom by an average of more than 3 percentage points. Ex ante real rates for the United Kingdom are understated for 1980, as discussed above, and it is surely true that the rise in world real rates in 1981 was not anticipated in 1979. But the ex 
post behavior of real interest rate differentials hardly helps to explain the initial "overshooting" of the United Kingdom's real exchange rate in 1979.

The last term in equation 2 is the residual or cumulative risk premium. The cumulative current account surplus has been advanced as a possible explanation of a bias toward overvaluation or lack of competitiveness. Seen as a "transfer problem," however, it is not at all clear why a redistribution of global wealth should affect any one country's competitive position. Neither the short-run case (in terms of relative portfolio preferences) nor the long-run case (in terms of differences in marginal propensities to spend out of wealth on United Kingdom goods) has been made. In our previous study of the first two years of the Thatcher experiment we mentioned, but did not attempt to quantify, the possibility of portfolio shifts as a partial explanation of the overvaluation of the pound sterling. We are in the same position today.

What does this inability to account satisfactorily for much of the misalignment of the pound sterling imply for the assessment of monetary policy? Given that the loss of competitiveness is not to be attributed to economic fundamentals-permanent changes in the equilibrium rate or temporary spells of relatively high real interest rates-policymakers were faced with options ranging from adhering firmly to the monetary targets whatever the consequences for interest rates and real and nominal exchange rates to trying to stabilize exchange rates and sacrificing domestic monetary targets. There is evidence of a compromise in which the broad money target was allowed to overrun when it could be shown that the strength of the pound sterling on the foreign exchanges was achieving many of the effects on inflation and output that tight domestic monetary policy was designed to achieve.

Ex ante the government had made an unequivocal commitment to the domestic monetary targets. In considering responses to alternative outcomes in March 1980 the Treasury noted:

To maintain a progressive reduction in monetary growth in these circumstances [changes in the domestic or foreign environment] it may be necessary to change policy in ways not reflected in the above projections....

But there would be no question of departing from the money supply policy, which is essential to the success of any anti-inflationary strategy. ${ }^{13}$

13. Financial Statement and Budget Report, 1980-81 (HMSO, March 1980), p. 19. 


\section{THE CREDIBILITY OF MONETARY POLICY}

Since the monetary targets have not been observed ex post, how has the government retained credibility? First, as explained above, the overruns were tolerated in circumstances in which the exchange rate was behaving as it would have in response to tight money, and also in cases in which other indicators showed signs of financial restraint. Second, and just as important, announcing an intermediate monetary target in the first place freed the authorities from promises to maintain full employment, positive growth, current balance, and so on and made their commitment to preventing inflation more credible.

In his paper on monetary targeting cited above, John Fforde is quite explicit about this implication of adopting the intermediate targets expressed in the government's counterinflationary strategy. He writes: it would have been possible to initiate such a strategy with a familiar "Keynesian", exposition about managing demand downwards, and with greater concentration on ultimate objectives than on intermediate targets. But this would have meant disclosing objectives for, inter alia, output and employment. This would have been a very hazardous exercise, and the objectives would either have been unacceptable to public opinion or else inadequate to secure a substantial reduction in the rate of inflation, or both. Use of strong intermediate targets, for money supply and government borrowing, enabled the authorities to stand back from output and employment as such and to stress the vital part to be played in respect of these by the trend of industrial costs. In short, whatever the subsequent difficulties of working with intermediate targets, they were vitally important at the outset in order to signal a decisive break with the past and enable the authorities to set out with presentational confidence upon a relatively uncharted sea. ${ }^{14}$

The third explanation of how credibility has been maintained follows logically. It has been argued that the adoption of intermediate targets involved the implicit rejection of the 1944 White Paper commitment to maintain high employment through Keynesian demand management. But one may go further and argue that it was this aspect of the counterinflationary strategy that was more important than the details of the monetary policy itself. This point is also made explicit in John Fforde's presentation:

the difficulties that have come to seem inherent in short-term monetary targetry are by no means fatal to the associated counterinflationary strategy once its

14. Fforde, "Setting Monetary Objectives,"' p. 207. 
practical credibility can be established by the perceived behavior of policy in response to the developing and disinflationary economic situation. For what matters is the refusal of the authorities to stimulate demand in "Keynesian" fashion, or to "reflate," as conditions develop that would in the past have justified and provoked such a response. The fact that the monetary targets have not concurrently been met, or that the meaning of particular developments in this or that aggregate has become very ambiguous, is of much less importance. ${ }^{15}$

Indeed, we would argue that the intermediate targets for the government deficit (as measured by the public sector borrowing requirement, the PSBR) that were initially put in place to support the monetary targets have, in practice, prevented the operation of Keynesian stabilization policy and have thus played a crucial role in sustaining the credibility of the anti-inflationary policy in the face of rising unemployment. This argument is developed in the next section.

\section{Fiscal Policy and the Medium-Term Financial Strategy}

Fiscal policy in the United Kingdom since 1980 has been powerfully influenced by the explicit medium-term strategy for reducing public sector borrowing as a percentage of GDP. To adhere to preannounced targets for borrowing has involved taking discretionary actions to counteract the built-in stabilizers that tend to increase the deficit in a slump and lower it in a boom.

\section{THE PSBR：TARGETS AND OUTCOMES}

Table 5 shows the targets for the PSBR as a percent of GDP at market prices. The projections embodied in the MTFS as it was first launched in the 1980 budget is given in the first row; entries decrease steadily from 3.8 percent in $1980-81$ to 1.5 percent in $1983-84$.

The actual outcome for 1980-81, 5.6 percent, shows a considerable overshooting of the target (though, as we argue below, the resulting fiscal stance was still contractionary given the slump in output and employment). In the second row, the budget for fiscal 1981, the target figures were revised upward, and there have been subsequent upward revisions in the last two budgets also. The tendency to revise the targets

15. Ibid. 
Table 5. Targets and Outcomes for the Public Sector Borrowing Requirement, Financial Years 1980-81 through 1985-86

Percent of GDP at market prices

\begin{tabular}{lcccccc}
\hline \multicolumn{1}{c}{ Item } & $1980-81$ & $1981-82$ & $1982-83$ & $1983-84$ & $1984-85$ & $1985-86$ \\
\hline Targets & & & & & & \\
$1980-81$ budget & 3.8 & 3.0 & 2.3 & 1.5 & $\ldots$ & $\ldots$ \\
$1981-82$ budget & $\ldots$ & 4.3 & 3.3 & 2.0 & $\ldots$ & $\ldots$ \\
$1982-83$ budget & $\ldots$ & $\ldots$ & 3.5 & 2.8 & 2.0 & $\ldots$ \\
1983-84 budget & $\ldots$ & $\ldots$ & $\ldots$ & 2.8 & 2.5 & 2.0 \\
Outcomes & 5.6 & 3.4 & $3.4^{\mathrm{a}}$ & $2.5^{\mathrm{a}}$ & $1.9^{\mathrm{a}}$ & $\ldots$ \\
\hline
\end{tabular}

Sources: Targets are from United Kingdom, Financial Statement and Budget Report, 1980-81 (Her Majesty's Stationery Office, 1981) and successive issues. Actuals for 1980-81 and 1981-82 are from Economic Trends, no. 358 (August 1983), pp. 6, 54; forecasts for 1982-83 to 1985-86 are from National Institute Economic Review, no. 104 (May 1983), p. 20, and from Financial Statement and Budget Report, 1983-84 (HMSO, 1983), p. 9.

a. Forecast.

successively upward has been partly offset, however, by an "undershooting" of those revised targets in the past three years. (Thus in 198182 , for example, the target was raised from 3 percent to 4.3 percent but the actual outcome was 3.4 percent.) This is evidence in part of the increasing effect of cash limits in planning public sector spending: after 1982-83, the government expenditure and financing plans are all expressed in cash terms with little indication of the real implications of such plans. ${ }^{16}$ Overall the designers of the MTFS could be satisfied with the results shown in the last row (including estimates for future years). Starting from a higher level than anticipated, the PSBR as a percentage of GDP has been brought down by more than 2 percentage points thus far and is forecast to fall by another $1 \frac{1}{2} 2$ points by $1984-85$.

\section{THE DEFICIT AND THE EFFECTS OF THE CYCLE}

The actual financial balance in the public sector as a percentage of GDP during the last five financial years is shown at the top of table 6 (first column). The deficit of almost 5 percent of GDP recorded by the previous Labour party administration in 1978-79 was almost halved by 1982-83; but the conflict between the Tories' plans to reduce the deficit and the pressure exerted on them by the built-in stabilizers (lower tax receipts and higher transfer payments) is also evident from the series. In 1980-81, which happened to be both the first year of the MTFS and of

16. See John A. Kay, The 1982 Budget (Blackwells, 1982), chap. 8, pp. 100-08. 
Table 6. Actual and Cyclically Adjusted Financial Balance for Different Aggregations of the Public Sector, 1978-83

Percent of GDP at market prices

\begin{tabular}{|c|c|c|c|c|c|}
\hline \multirow[b]{2}{*}{ Sector and year } & \multirow[b]{2}{*}{$\begin{array}{l}\text { Actual } \\
\text { balance }\end{array}$} & \multirow{2}{*}{$\begin{array}{l}\text { Change } \\
\text { from } \\
\text { previous } \\
\text { year }\end{array}$} & \multirow[b]{2}{*}{$\begin{array}{l}\text { Built-in } \\
\text { stabilizer }\end{array}$} & \multicolumn{2}{|c|}{$\begin{array}{c}\text { Cyclically adjusted } \\
\text { budget change }\end{array}$} \\
\hline & & & & $\begin{array}{l}\text { United } \\
\text { Kingdom }\end{array}$ & $O E C D^{\mathrm{b}}$ \\
\hline \multicolumn{6}{|l|}{$\begin{array}{l}\text { Public sector } \\
\text { (financial years) }\end{array}$} \\
\hline $1978-79$ & -4.9 & $\ldots$ & $\ldots$ & $\ldots$ & $\ldots$ \\
\hline $1979-80$ & -3.9 & 1.0 & 0.1 & 0.9 & $\ldots$ \\
\hline $1980-81$ & -5.1 & -1.2 & -3.1 & 1.9 & $\ldots$ \\
\hline $1981-82$ & -2.6 & 2.6 & -1.9 & 4.5 & $\ldots$ \\
\hline $1982-83$ & -3.2 & -0.6 & -0.7 & 0.1 & $\ldots$ \\
\hline Sum of changes & $\ldots$ & 1.8 & -5.6 & 7.4 & $\ldots$ \\
\hline $\begin{array}{l}\text { Sum of weighted } \\
\text { changes }^{c}\end{array}$ & $\cdots$ & 0.2 & -3.4 & 3.7 & $\ldots$ \\
\hline \multicolumn{6}{|l|}{$\begin{array}{l}\text { General government } \\
\text { (calendar years) }\end{array}$} \\
\hline 1979 & -3.1 & $\ldots$ & $\ldots$ & $\ldots$ & $\ldots$ \\
\hline 1980 & -3.2 & -0.1 & -1.0 & 0.9 & 0.1 \\
\hline 1981 & -2.0 & 1.2 & -2.2 & 3.4 & 0.6 \\
\hline 1982 & -2.0 & 0.0 & -1.2 & 1.2 & 0.0 \\
\hline 1983 & -2.1 & -0.1 & -0.6 & 0.5 & 0.3 \\
\hline Sum of changes & $\ldots$ & 1.0 & -5.0 & 6.0 & 1.0 \\
\hline \multicolumn{6}{|l|}{$\begin{array}{l}\text { Central government } \\
\text { (calendar years) }\end{array}$} \\
\hline 1979 & -5.3 & $\ldots$ & $\ldots$ & $\ldots$ & $\ldots$ \\
\hline 1980 & -4.9 & 0.4 & -1.8 & 2.2 & 0.1 \\
\hline 1981 & -4.1 & 0.8 & -2.0 & 2.8 & 0.2 \\
\hline 1982 & -2.8 & 1.3 & -0.4 & 1.7 & 0.1 \\
\hline 1983 & -2.7 & 0.1 & -0.2 & 0.3 & -0.4 \\
\hline Sum of changes & $\ldots$ & 2.6 & -4.4 & 7.0 & 0.0 \\
\hline
\end{tabular}

Sources: The public sector balance is from Economic Trends, no. 358 (August 1983), pp. 6, 58; stabilizers are from National Institute Economic Review, no. 103 (February 1983), p. 8; general government data are from Organization for Economic Cooperation and Development, OECD Economic Outlook (OECD, December 1982), pp. 23-24; and central government data are from International Monetary Fund, World Economic Outlook (IMF, 1983), p. 219.

a. Second column minus third column.

b. Seven largest countries.

c. The concept of demand-weighted deficit is intended to show the "first round" effect of the budget on GDP after allowing for savings and imports leakages. See National Institute Economic Review, no. 99 (February 1982), p. 95 .

the current slump, the measured deficit rose by a little more than 1 percent of GDP. (The year-to year changes are shown in the second column.)

A clearer picture of the effect of falling tax revenues and rising unemployment benefits on the finances of the public sector is shown in 
the third column, which presents the "cyclical adjustments" computed by the National Institute of Economic and Social Research. For 198081 alone the effect of the stabilizers is 3.1 percent of GDP, and the cumulated total between $1979-80$ and $1982-83$ is more than 5 percent. To register declines in the actual deficit against such pressures for it to increase automatically required a marked contraction in fiscal policy; and the last column, when cumulated, shows that the cyclically adjusted deficit was reduced by more than 7 percent.

Estimates of cyclically adjusted deficits are highly dependent on the assumed trend growth of potential GDP, which the National Institute of Economic and Social Research calculated to be 2.5 percent; but the same general picture emerges from calculations for the financial balance of general government-that is, excluding public corporations-carried out by the OECD and for the balance of the central government carried out by the International Monetary Fund. Their figures, for calendar years, are shown in table 6 . They also allow some comparison to be made between fiscal policy in the United Kingdom and the average of the seven largest OECD economies.

The OECD series for the financial balance of the United Kingdom's general government has a smoother profile, and shows an overall reduction of 1 percent between calendar years 1979 and 1983. The cumulated effect of the built-in stabilizers is 5 percent of GDP, which yields a shift of 6 percentage points to surplus in the cyclically adjusted financial balance (see the fourth column). For the seven largest OECD economies, including the United Kingdom and two other countries that were implementing medium-term strategies to reduce their deficits, the shift to surplus in their high-employment deficits was only 1 percent.

As the OECD was collectively moving into recession, all countries experienced upward pressure from the built-in stabilizers that, taken collectively, they did not offset, allowing the weighted average deficit to increase by 2.4 percent according to OECD estimates. However, the United Kingdom, which experienced one of the sharpest recessions, more than offset the effect of the stabilizers, as we have shown.

The International Monetary Fund's figures for the central government financial balance show much the same overall profile as the OECD calculations just discussed (see table 6). The move to a surplus of 2.6 percent of GNP over the period shown in the second column was achieved despite the pressure of the stabilizers whose cumulated effect 
was a 4.4 percent shift toward deficit. The cyclically adjusted budget change is thus a 7 percent shift to surplus-what the International Monetary Fund calls a 7 percent negative fiscal impulse-over the four calendar years 1980 to $1983 .{ }^{17}$ For the seven largest OECD countries the corresponding fiscal impulse for these years is precisely zero, as shown in the last column.

All three sets of figures in table 6 from separate sources covering, respectively, the public sector, general government, and central government suggest that fiscal policy in the United Kingdom under the MTFS has been contractionary-much more contractionary, it would appear, than the average of the largest seven OECD countries.

By Keynesian principles of the determination of aggregate demand and output, the depth of the depression in the United Kingdom can be partly explained by the tight fiscal stance induced by the MTFS. But according to those principles, it would not be correct to use the shift in the cyclically adjusted deficit itself as a measure of the impact of public spending and taxation on aggregate demand. For this purpose it is conventional to "demand weight" the items in the balance; the changes in the demand-weighted balance are given in the seventh row of table 6 .

According to these figures, the substantial move toward surplus in the unadjusted deficit had little effect on the demand-weighted deficit, which hardly changed during the period from 1978-79 to 1982-83, according to the National Institute of Economic and Social Research. But the built-in stabilizers, by these figures, would have added 3.4 percent to demand had they been allowed to operate. The resulting estimate of the cumulated change in the cyclically adjusted, weighted deficit is 3.7 percent, as shown in the fourth column, half the figure for the unweighted equivalent.

This quantitative conclusion, that the demand effect of the government's spending and tax program has fallen almost 4 percent behind the potential growth of the economy, depends on the 2.5 percent growth of potential assumed by the National Institute of Economic and Social Research. But cutting back the assumed potential growth rate by 1 percentage point would still leave the result that the government's fiscal stance has effectively removed about 3 percent from demand in the economy. 
Table 7. Adjusting the Public Sector Financial Deficit to Reflect the "True" Cost of Debt Service, 1979-82

Percent of GDP at market prices unless otherwise specified

\begin{tabular}{|c|c|c|c|c|c|}
\hline Item & 1979 & 1980 & 1981 & 1982 & Average \\
\hline Public sector financial deficit & 4.3 & 4.7 & 3.5 & 2.9 & 3.9 \\
\hline Interest cost & 4.1 & 4.3 & 4.6 & 4.5 & 4.4 \\
\hline True cost of debt service & 0.5 & 0.5 & 0.6 & 0.7 & 0.6 \\
\hline Implied adjustment ${ }^{\mathrm{a}}$ & 3.0 & 3.2 & 3.3 & 3.1 & 3.2 \\
\hline Adjusted public sector deficit ${ }^{b}$ & 1.3 & 1.5 & 0.2 & -0.2 & 0.7 \\
\hline Memoranda & & & & & \\
\hline Public sector net liabilities & 40.1 & 37.7 & 38.4 & 38.4 & 38.6 \\
\hline $\begin{array}{l}\text { Bank of England's inflation } \\
\text { adjustments }\end{array}$ & 7.5 & 5.4 & 4.8 & n.a. & \\
\hline $\begin{array}{l}\text { Real long-run interest rate, } \\
\text { percent per yearc }\end{array}$ & 2.5 & 2.5 & 2.5 & 2.9 & $\ldots$ \\
\hline
\end{tabular}

Sources: Public sector deficit and GDP are from Economic Trends, no. 358 (August 1983), pp. 6, 58; net liabilities, inflation adjustments by the Bank of England, and interest cost before 1982 are from Bank of England Quarterly Bulletin, vol. 22 (June 1982), pp. 241-42; interest cost for 1982 is the authors' estimate; and the true cost is from Marcus Miller and Simon Babbs, "The True Cost of Debt Service and the Public Sector Financial Deficit," paper presented at the Association of University Teachers of Economics Conference, Oxford, England, April 1983, table 6. The real long-run interest rate for 1981-82 is from Financial Times, various issues.

n.a. Not available.

a. Calculated as 85 percent of interest cost, assuming a 15 percent average tax rate, minus the true cost.

b. The financial deficit minus the adjustment.

c. Data for 1979-80 are assumed to be the same as for 1981 .

In the light of this evidence it is not so surprising to see the economy falling about 7 percent below the trend prevailing from 1973 to 1982 (see figure 3).

\section{ADJUSTING FOR INFLATION}

The public sector deficit includes a substantial volume of interest payments. With high inflation and net monetary liabilities of the public sector averaging almost 40 percent of GDP during the past four years, interest payments have been more than 4 percent of GDP, as shown in the second row of table 7, while the public sector financial deficit as a whole, shown in the first row, averaged 3.9 percent in the last four calendar years.

In times of inflation, however, nominal interest transfers do not measure the "real" interest cost of borrowing, and the Bank of England publishes a series of inflation adjustments that may be applied to the nominal interest series. The effect of using these adjustments is, roughly, to replace nominal interest rates by real interest rates. As the latter have 
varied substantially over the past few years, however, the cost of debt service is probably better measured by using a long-term rate; and the floating of some long-term dated indexed stock in 1981 now provides data on long-term real rates (see the memoranda in table 7).

It may seem paradoxical to combine the multiplier, whose existence depends on current disposable income having an effect on current consumption demand over and above its contribution to permanent income, with a smoothed, permanent, real debt-service concept. The reason is that we believe permanent real interest income, as calculated in the table, is a better approximation of the actual flow of disposable interest income to the ultimate wealth-owning and spending units than the uncorrected figures or the figures corrected only for current inflation. This is because most government debt is held by institutional investors such as pension funds with long time horizons and superior access to the capital markets. They effectively transform the volatile series of current interest income and capital gains into a much smoother series of disbursements to the ultimate wealth owners. No similar private institutions exist for smoothing out factor incomes, and the stabilizing role of the government consists to a large extent in using its tax-transfer and borrowing powers to keep private disposable income in line with (potential) private permanent income.

With long-run real rates of less than 3 percent, the after-tax "true" cost of debt service estimated in the third row of table 7 averages only a little over 0.5 percentage point of GDP, rising to 0.7 point over the period. The adjustment (fourth row) that this implies for measured interest payments is fairly constant at about 3 percentage points of GDP.

The "real" public sector financial deficit, having been adjusted to reflect this long-run measure of the cost of debt service, is shown in the fifth row. It has the same trend as the conventional PSFD (first row) but is centered around a position of budget balance: instead of falling from about 5 percentage points of GDP to just under 3 points, the real deficit moves from 1.3 points of GDP to a surplus of 0.2 in 1982. Because the adjustments in the table are fairly constant, a cyclically adjusted real deficit would show the same pattern as the measured deficit discussed above, though at a lower level.

The message conveyed by these estimates of real deficits is clear enough. Pursuing a medium-term strategy for reducing nominal deficits (as a percentage of nominal GDP) at a time of high inflation and worldwide 
Table 8. The Tax Burden since 1978

Percent

\begin{tabular}{ccccc}
\hline Year & $\begin{array}{c}\text { Average } \\
\text { tax } \\
\text { burden }^{\text {a }}\end{array}$ & $\begin{array}{c}\text { Tax rate on employes, } \\
\text { average earnings }\end{array}$ & $\begin{array}{c}\text { Marginal } \\
\text { direct tax } \\
\text { rate of } \\
\text { married } \\
\text { couple }\end{array}$ \\
\hline 1978 & 34.11 & 47.0 & 54.6 & 33.6 \\
1979 & 34.93 & 48.0 & 55.1 & 30.1 \\
1980 & 36.32 & 49.0 & 55.4 & 30.2 \\
1981 & 38.54 & 51.5 & 56.9 & 31.0 \\
1982 & 39.50 & 51.4 & 57.3 & 32.4 \\
1983 & n.a. & 51.2 & 57.5 & 33.2 \\
\hline
\end{tabular}

Sources: Average tax burden is from Economic Trends, no. 358 (August 1983), pp. 6, 58; all other data are from A. W. Dilnot and C. N. Morris, "The Tax System and Distribution 1978-83," Fiscal Studies, vol. 4 (May 1983), tables 2 and 3, p. 59.

a. Direct and indirect taxes, national insurance contributions, and so on as a percentage of GDP at market prices, expenditure estimate.

b. Direct and indirect taxes, national insurance contributions, and so on as a percentage of gross income (including employers' national insurance contribution).

c. Marginal rate of income tax plus employees' national insurance contributions for a married couple in the basicrate band.

recession has involved "balancing the budget"' in real terms on average, with a trend movement into surplus.

\section{THE TAX BURDEN}

Since the last full year under a Labour government in 1978, the burden of taxes in the United Kingdom has risen markedly. The first column of table 8 shows how a macroeconomic index of the average tax burden (total direct plus indirect taxes and national insurance contributions as a proportion of GDP) rises by 5.4 percentage points between 1978 and 1982. The second and third columns give the total (direct plus indirect) average and marginal tax rates of an employee on average earnings. These microeconomic measures rise over the same five-year period by 4.4 and 2.7 percentage points, respectively. Although marginal direct tax rates have been lowered significantly for the wealthy, the picture is different for persons with average incomes, as the fourth column indicates. The overall progressivity of the tax system has declined. ${ }^{18}$ Most of the increase is accounted for by higher value-added tax and

18. See A. W. Dilnot and C. N. Morris, "The Tax System and Distribution 1978-83," Fiscal Studies, vol. 4 (May 1983), pp. 54-64. 
Table 9. Public Expenditure According to Successive Plans, 1978-79 to 1985-86

Indexes, 1978-79 $=100$ unless otherwise specified

\begin{tabular}{|c|c|c|c|c|c|c|c|c|}
\hline Item & $1978-79$ & $1979-80$ & $1980-81$ & $1981-82$ & $1982-83$ & $1983-84$ & $1984-85$ & $1985-86$ \\
\hline \multicolumn{9}{|c|}{ Total expenditure ${ }^{\mathrm{a}}$} \\
\hline March 1980 & 100.0 & 99.6 & 99.6 & 98.7 & 96.5 & 95.8 & $\ldots$ & $\ldots$ \\
\hline March 1981 & 100.0 & 101.5 & 105.6 & 105.3 & 103.6 & 100.7 & $\ldots$ & $\ldots$ \\
\hline March 1982 & 100.0 & 101.0 & 103.6 & 106.3 & 107.3 & 105.7 & 105.3 & $\ldots$ \\
\hline February 1983 & 100.0 & 101.0 & 103.3 & 105.7 & 106.1 & 107.0 & 107.4 & 107.9 \\
\hline \multicolumn{9}{|l|}{ Memoranda } \\
\hline $\begin{array}{l}\text { Public expendi- } \\
\text { ture }^{b}\end{array}$ & 41.0 & 40.5 & 43.0 & 44.5 & 44.0 & $\cdots$ & - & $\cdots$ \\
\hline \multicolumn{9}{|l|}{ Market price } \\
\hline GDP & 100.0 & 101.4 & 98.4 & 97.1 & 99.7 & $\ldots$ & $\ldots$ & $\ldots$ \\
\hline
\end{tabular}

Sources: Cost indexes are from Government's Expenditure Plans 1983-84 to 1985-86. Third Report from the House of Commons Treasury and Civil Service Committee, sess. 1982-83 (HMSO, 1983), p. 24; ratios are from Government's Expenditure Plans 1983-84 to 1985-86, presented to Parliament by the Chancellor of the Exchequer, Cmnd. 8789, vol. 1 (HMSO, 1983), p. 9; and GDP is from Economic Trends, no. 358 (August 1983), p. 6. a. Includes net debt interest.

b. As a percentage of GDP at market prices.

other indirect taxes, although employees' national insurance contributions have also risen sharply. The increase in the tax burden in the United Kingdom stands in sharp contrast to the large tax cuts implemented by the Reagan administration. This contrast extends to the overall stance of budgetary policy, which is expansionary in the United States but very contractionary in the United Kingdom.

PUBLIC EXPENDITURE: PLANS, PERFORMANCE, AND PROSPECTS

The failure to reduce public expenditure as planned has already been noted in discussing successive modifications to the MTFS. In what follows we look at this "failure" in more detail to identify how the overshooting of planned spending came about. We briefly go on to describe and criticize the conclusions now apparently being drawn from this experience about the prerequisites for fiscal balance over the longer term.

In table 9, reproduced from evidence supplied to the Treasury Committee by Terry Ward, public spending in real terms with 1978-79 as a base is shown as envisaged by successive plans and embodied in annual White Papers. The first public expenditure White Paper of the Conservative government, published in March 1980, anticipated a decline of total expenditure to 95.8 percent of this base by 1983-84. The latest White Paper of February 1983, in contrast, has an expenditure 
total for 1983-84 that is 12 percent higher, that is, 100.2 relative to base. Ward notes the marked tendency for the cost of future expenditure to be revised upward year after year; it is also apparent that actual expenditure has tended to undershoot such revised plans. ${ }^{19}$

The ratio of public expenditure to GDP is by convention, but without economic foundation, used as a bench mark of the weight imposed by the public sector on the economy, and the relevant ratio is shown in the memoranda in the table. Public expenditure failed to fall at about 1 percent a year over the four financial years to 1982-83 (as envisaged in the first White Paper), but rather rose at a rate of 1.5 percent a year over the period. This, together with no growth in GDP over the base year, has pushed the ratio of true expenditures to GDP up 3 percentage points from 41 percent to an estimated 44 percent in 1982-83.

By comparing initial plans with resulting outcomes (to 1982-83) for the individual programs that make up the planning total, one can identify three main areas in which spending substantially overshot: social security, which includes the cost of unemployment benefits and supplementary benefits; expenditure for industry, energy, trade, and employment, which includes industrial support and special employment measures; and the rise in lending to nationalized industries. Defense spending did not overshoot noticeably, despite the Falkland Islands campaign. The message that emerges from this examination is that a major recession whose depth, length, and employment consequences were underestimated had the effect of increasing public spending on unemployment compensation, industrial support, and employment measures and raising the borrowing needs of nationalized industries.

To those of a Keynesian persuasion these are manifestations of the automatic stabilizers at work that would hardly be looked upon as reasons for treating the actual course of public spending as a failure of policy. The Thatcher government has, of course, condoned the observed increases; but it now is apparently aiming to reverse these increases in order to cut taxes.

If the economy were to regain its 1978-79 utilization of potential, the rise in the expenditure ratio would, by and large, vanish. But the objective of policy is not to achieve such output targets: it is directed at "ensuring the conditions for sustainable growth," not at utilization or unemploy-

19. Memorandum by Terry Ward, appendix 1 to Government's Expenditure Plans 1983-84 to 1985-86, Third Report from the House of Commons Treasury and Civil Service Committee (hereafter Treasury Committee), sess. 1982-83 (HSMO, 1983), pp. 17-24. 
ment rates. What then are the prospects for the future of public expenditure? Some indications of official thinking have recently been revealed. ${ }^{20}$ It appears to be assumed that, without a major policy shift, public expenditure in real terms will continue for the rest of the decade to grow at more or less the same rate as that observed in table 9-that is, roughly 1.5 percent a year, including debt interest, with unemployment staying at 3 million if GDP growth is low but falling to 2 million by 1990 if economic growth is high. Official real expenditure projections are, surprisingly, not very sensitive to the difference in unemployment in these two scenarios. A high annual growth rate-3 percent from now until the end of the decade-ensures that the public expenditure ratio falls to 40 percent by the end of the decade. A low growth rate- 0.5 percent a year-by contrast will push the ratio up to almost 47 percent by the end of the decade.

The second Thatcher government wants to restrict the PSBR to about 2 percent of GDP and to reduce taxes if possible. To do this, two "structural" solutions are currently being examined. The first, which is to a large extent cosmetic, is "privatization," selling a majority interest in industrial activities of the public sector. The proceeds of such sales would reduce the PSBR, and the spending and borrowing of the privatized industry would not count as public expenditure. The second policy shift being considered is to reduce the size and extent of the welfare state. This is potentially much more significant as it would involve a diminution of the government's involvement in the health, education, and welfare transfer programs that currently constitute over 50 percent of the program total. ${ }^{21}$

\section{Inflation and Unemployment}

The first priority in the design of macroeconomic policy since 1979 has been the reduction of inflation without explicit recourse to incomes

20. See, for example, David Blake, "Has the Think Tank Got It Wrong about Public Spending?" The Times, November 8, 1982.

21. The official argument that radical cuts in spending may be financially inevitable has been, however, challenged both because of its narrow focus on the PSBR and its statistical assumptions. See Willem H. Buiter, "The Theory of Optimum Deficits and Debt," Discussion Paper (London School of Economics, Centre for Labour Economics, forthcoming); and the report discussed in "The Crisis that Never Was," The Economist, October 15, 1983, pp. 45-47. 
Table 10. Wage and Price Inflation, 1978 to 1983:1

Percent $^{\mathrm{a}}$

\begin{tabular}{rcccccc}
\hline & $\begin{array}{c}\text { Average } \\
\text { earnings, } \\
\text { entire }\end{array}$ & $\begin{array}{c}\text { Retail } \\
\text { price } \\
\text { index }\end{array}$ & $\begin{array}{c}\text { Tax and } \\
\text { price } \\
\text { index }\end{array}$ & $\begin{array}{c}\text { GDP } \\
\text { deflatorat } \\
\text { factor } \\
\text { cost }\end{array}$ & $\begin{array}{c}\text { Real con- } \\
\text { sumption } \\
\text { earnings }\end{array}$ & $\begin{array}{r}\text { Real } \\
\text { product } \\
\text { earnings }^{c}\end{array}$ \\
\hline $1978: 4$ & 13.8 & 8.1 & 3.8 & 10.9 & 10.0 & 2.9 \\
$1979: 1$ & 13.9 & 9.6 & 6.6 & 10.2 & 7.3 & 3.7 \\
2 & 13.4 & 10.6 & 12.9 & 12.6 & 0.5 & 0.8 \\
3 & 15.7 & 16.0 & 13.6 & 13.9 & 2.1 & 1.8 \\
4 & 18.5 & 17.2 & 14.9 & 16.6 & 3.6 & 1.9 \\
$1980: 1$ & 19.7 & 19.1 & 16.8 & 18.0 & 2.9 & 1.7 \\
2 & 21.4 & 21.5 & 18.0 & 19.8 & 3.4 & 1.6 \\
3 & 22.2 & 16.4 & 17.8 & 20.1 & 4.4 & 2.1 \\
4 & 19.5 & 15.3 & 16.6 & 17.7 & 2.9 & 1.8 \\
$1981: 1$ & 16.5 & 12.7 & 13.5 & 15.2 & 3.0 & 1.3 \\
2 & 13.0 & 11.7 & 15.2 & 11.5 & -2.2 & 1.5 \\
3 & 11.4 & 11.2 & 14.7 & 9.4 & -3.3 & 2.0 \\
4 & 11.1 & 11.9 & 15.5 & 7.2 & -4.4 & 3.9 \\
$1982: 1$ & 11.1 & 11.1 & 14.6 & 5.6 & -3.5 & 5.5 \\
2 & 10.1 & 9.4 & 9.7 & 7.8 & 0.4 & 2.3 \\
3 & 8.5 & 8.0 & 8.8 & 6.5 & -0.3 & 2.0 \\
4 & 7.7 & 6.2 & 6.7 & 7.8 & 1.0 & -0.1 \\
$1983: 1$ & 8.8 & 4.9 & 5.2 & 7.8 & 3.6 & 1.0 \\
\hline
\end{tabular}

Sources: Economic Trends, no. 358 (August 1983), pp. 5, 6, 40, 42, and similar tables in Economic Trends: Annual Supplement, 1983 Edition.

a. Percent changes are from same quarter one year earlier.

b. Change in average earnings minus change in tax price index.

c. Change in average earnings minus change in the GDP deflator.

policy. The course of recent wage and price inflation is given in table 10 . In pursuit of this objective the government has apparently dropped high employment as an avowed short- and medium-term objective of policy, and unemployment has grown at an alarming rate.

Figure 5 shows both inflation and unemployment for the period immediately before the election of June 1979 and in the interval since then. With the breakdown of incomes policy in 1978, inflation increased in the first two quarters of 1979; but the year-to-year increase in retail prices then exhibited a sharp rise for four quarters and peaked at more than 20 percent in 1980:2. The value-added tax increase in the June budget of 1979 was estimated to have added 4 percentage points to the retail price index for 1979:3 and, because this remains in year-to-year figures for four quarters, it would account for most of the sharp increase in that quarter, and for the sharp decrease one year later. Inflation has fallen steadily since from its peak of 21.5 percent in early 1980 . 
Figure 5. Inflation and Unemployment in the United Kingdom, 1977:1 through 1983:3

Retail price index

(percent change from previous year)

Unemployment rate

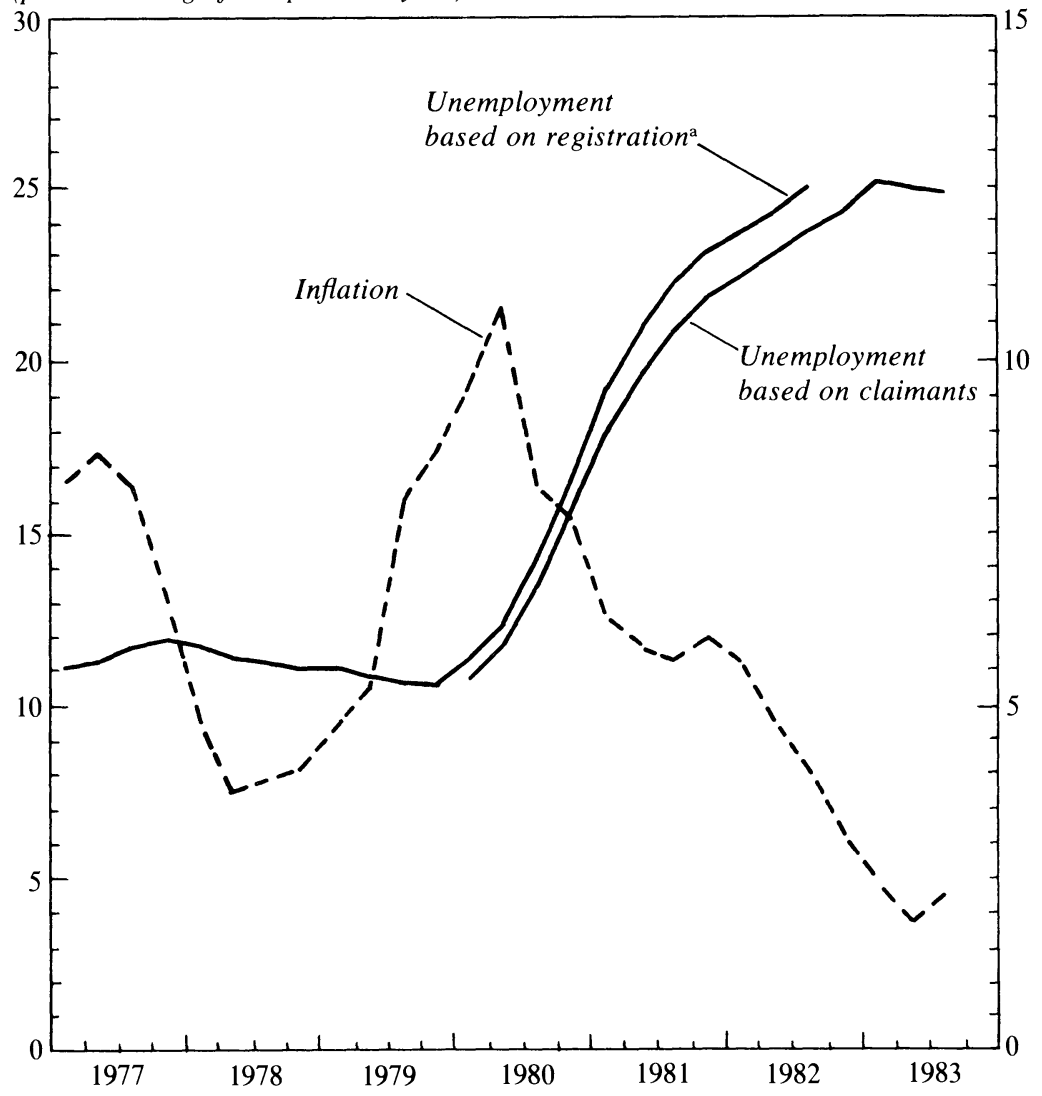

Source: Economic Trends, no. 358 (August 1983), pp. 36, 42.

a. The change in the basis for counting the unemployed was carried out in October 1982. The series for the new basis as shown is from an earlier date, however, to highlight its increasing divergence from the old series.

Unemployment has, on the other hand, risen without a break since 1979:2 to levels without precedent in the United Kingdom since the 1930s. Thus from a plateau of between 5 and 6 percent in 1977-78, which was a record for the United Kingdom after World War II, unemployment doubled by late 1981 and has gone on rising since then. Because of a subsequent shift in the basis of measurement, from those registering as unemployed to those claiming benefits, the old series is no longer continued; but the new series shows the same pattern, at a slightly lower level. 
Table 11. Output, Unemployment, and Inflation, 1979-83

\begin{tabular}{|c|c|c|c|c|c|c|}
\hline Item & 1979 & 1980 & 1981 & 1982 & 1983 & Sum \\
\hline \multicolumn{7}{|l|}{ GDP (index, $1975=100$ ) } \\
\hline Trend of 1.6 percent $^{\mathrm{a}}$ & 110.7 & 112.4 & 114.3 & 116.2 & 118.1 & $\ldots$ \\
\hline Actual & 110.7 & 108.0 & 105.4 & 106.1 & $108.2^{\mathrm{b}}$ & \\
\hline Gap (percent) & 0 & 3.9 & 7.8 & 8.7 & $8.4^{\mathrm{b}}$ & 28.8 \\
\hline \multicolumn{7}{|l|}{ Unemployment $^{c}$} \\
\hline Number (millions) & 1.2 & 1.6 & 2.4 & 2.8 & $3.0^{\mathrm{b}}$ & $\ldots$ \\
\hline Rate (percent) & 5.1 & 6.4 & 10.0 & 11.7 & $12.5^{\mathrm{b}}$ & $\ldots$ \\
\hline "Bulge'd & 0 & 1.3 & 4.9 & 6.6 & $7.4^{\mathrm{b}}$ & 20.2 \\
\hline Inflation (percent growth) ${ }^{\mathrm{e}}$ & 13.4 & 18.0 & 11.9 & 8.6 & $4.6^{\mathrm{b}}$ & $\ldots$ \\
\hline
\end{tabular}

Sources: GDP at factor cost, average estimate, unemployment, and inflation are from Economic Trends, no. 358 (August 1983), pp. 6, 36, 42. Forecast of GDP at factor cost, compromise estimate, is from United Kingdom, Financial Statement and Budget Report, 1983-84 (HMSO, 1983), pp. 18-20; the forecast of unemployment is from Government's Public Expenditure Plans 1983-84 to 1985-86, presented to Parliament by the chancellor of the exchequer, Cmnd. 8789, vol. 2 (HMSO, 1983), p. 65. Number of unemployed in millions is converted to rate using 1982 labor force data. The forecast of inflation is from the government's Autumn Statement (H.M. Treasury, November 1983), p. 17, and Economic Trends, no. 360 (October 1983), p. 42.

a. Average of high (2.5) and low (0.75) growth trend considered by the government in forecasting public spending in the first half of the 1980s.

b. Forecast.

c. Excluding school leavers and counted on the basis of claims.

d. Increase relative to 1979 rate.

e. Percent increase in general index of retail prices from same quarter one year earlier.

Table 11 shows that the number of unemployed (excluding school leavers) on the new basis rose from 1.2 million in 1979 to 2.4 million in 1981 , and to 2.8 million in 1982 ; and this number is officially forecast to rise to 3 million in 1983. ${ }^{22}$ Thus while inflation has fallen from an average rate of 13.4 percent in 1979 to a forecast average of 4.6 percent in 1983, unemployment increased rapidly to more than 12 percent of the labor force. The cumulative total of unemployment in excess of the rate prevailing in 1979 now stands at 20 point-years.

The rise in the number of long-term unemployed, shown in table 12, is particularly startling. From a little more than 3 million unemployed in October 1982 (using the new basis of measurement, persons claiming benefits) 1 million had been unemployed for more than a year. Although unemployment increased by 1 million between October 1980 and October 1982 , there was no significant increase in the number unemployed for up

22. The conventional total unemployment figure understates both the level of and the recent increase in unemployment. Special employment and training schemes covered 293,000 people in 1979 and 534,000 in 1982 . The estimated effect on the registered unemployed total rises from 180,000 in 1979 to 300,000 in 1982. See OECD Economic Surveys: United Kingdom (OECD, February 1983), p. 58. 
Table 12. Unemployment Duration, October 1980 to October 1982

Thousands of persons

\begin{tabular}{lcccr}
\hline & & & \multicolumn{2}{c}{ October 1982 } \\
\cline { 3 - 5 } $\begin{array}{c}\text { Duration of } \\
\text { unemployment }\end{array}$ & $\begin{array}{c}\text { October } \\
(n=\text { number of weeks) }\end{array}$ & $\begin{array}{c}\text { October } \\
1980\end{array}$ & $\begin{array}{c}\text { Based on } \\
\text { registra- } \\
\text { tion }\end{array}$ & $\begin{array}{c}\text { Based on } \\
\text { claims }\end{array}$ \\
\hline$n \leq 2$ & 176.4 & 160.5 & 157.0 & 196.0 \\
$2<n \leq 4$ & 164.7 & 170.7 & 163.7 & 166.3 \\
$4<n \leq 8$ & 273.4 & 332.0 & 363.6 & 350.2 \\
$8<n \leq 13$ & 261.1 & 279.7 & 271.5 & 242.4 \\
$13<n \leq 26$ & 452.7 & 571.6 & 537.0 & 492.5 \\
$26<n \leq 52$ & 333.5 & 689.5 & 632.9 & 612.1 \\
$n>52$ & 401.1 & 784.6 & $1,169.6$ & 989.2 \\
$\quad$ Total unemployed & $2,062.9$ & $2,988.6$ & $3,295.1$ & $3,049.0$ \\
\hline
\end{tabular}

Source: Employment Gazette, vol. 91 (February 1983), table 2.8.

to four weeks and only a slight increase in the number unemployed for less than six months. But the number of unemployed for more than a year rose by 588,000 , and almost a third of this increase was for persons less than twenty-five years old. ${ }^{23}$ For adult males this increase in duration indicated a reduction in flows out of unemployment rather than an increase in flows into unemployment.

The rise in unemployment reflected a national decline in employment that was highly concentrated in the manufacturing sector, which in 1979 accounted for only about 30 percent of total employment. Total employment between 1979 and 1982 declined by 6.1 percent or a little more than 1.5 million persons; but manufacturing employment declined by 20 percent and accounted for almost all of the drop in total employment.

Table 11 includes a crude estimate of the conventional output "gap"the difference between actual output (real GDP, compromise estimate) and trend potential as a percent of potential. The trend growth rate assumed for this purpose is 1.6 percent a year, a simple average of the high ( 2.5 percent) and low ( 0.75 percent) GDP growth trends considered by the government for the first half of the 1980s in making its longterm spending forecasts. Applying this trend to GDP in 1979 provides a path below which actual GDP fell by about 4 percentage points in 1980 and by an additional 4 points in 1981, but it remained fairly constant 
at about 8 percent below trend in 1982 and 1983 . This performance adds up to a cumulative output gap of 29 percentage point-years of potential GDP by $1983 .{ }^{24}$

\section{THE TRADE-OFF BETWEEN INFLATION AND UNEMPLOYMENT}

The newly constituted Treasury Committee of the House of Commons conducted a wide-ranging enquiry into monetary policy in 1980 and 1981 . It received evidence from several sources on the inflation-unemployment trade-off.

Among the witnesses there emerged a clear difference of opinion between those who classified themselves as monetarists and those who did not. While the former were sanguine, the latter were by and large pessimistic about the costs of curbing inflation by the monetary and fiscal policies embodied in the MTFS plan.

Nicholas Kaldor, writing in July 1980, first warned

As there is no real precedent in Britain for a Government embarking on a policy of deflation with the explicit object of bringing down the rate of pay settlements to a non-inflationary level, it is impossible to predict the outcome. ${ }^{25}$

but he went on to say,

to generate enough unemployment to cause a collapse in real wage resistance, the rise in unemployment must become much faster than hitherto. . . . The Manpower Services Commission recently estimated that unemployment will not reach the 2 million level until the end of 1981 . For the strategy to succeed it would need to be more like 3 million. ${ }^{26}$

The National Institute of Economic and Social Research also forecast unemployment rising to almost 2 million by the end of 1981 but without a substantial reduction in inflation-presumably because "despite intensive econometric investigation (of data on the United Kingdom) we have failed to discern an effect of unemployment on wage inflation when recent years are included." 27

24. This trend is higher, but only marginally higher, than the trend of 1.3 percent a year observed for peak-to-peak GDP from 1973 to 1979 (see figure 2).

25. Memorandum by Lord Kaldor, in Memoranda on Monetary Policy, House of Commons Treasury and Civil Service Committee, sess. 1979-80 (HMSO, 1980), p. 96.

26. Ibid., p. 97.

27. Memorandum by the National Institute of Economic and Social Research, in Memoranda on Monetary Policy, pp. 150, 157. 
James Tobin, in his testimony, began by citing figures for the United States, where

the evidence of the past is that an extra point of unemployment for a year would reduce the ongoing domestic rate of wage and price inflation by maybe a third of a point or at most a half of a point. ${ }^{28}$

He continued,

I have seen conflicting estimates of what the corresponding coefficient for that is in the United Kingdom. Some are about the same as for the United States, others saying that the response is quicker in the United Kingdom than the United States. I do not know about that. One ought to say that the theory that one might regard as being the underpinnings of the present policy here says that when you have made this public threat about never giving in then the response will be quicker than past estimates of it would suggest, because the unions, managements, workers, private sector agents all over the economy, will feel that they are not going to be bailed out by compensatory or accommodative monetary and fiscal policies in the future and that will make them disinflate faster. I must say that I am quite skeptical about that, on the grounds that that kind of a threat is a threat to everybody in general and nobody in particular. ${ }^{29}$

In sharp contrast to these gloomy assessments, witnesses of a monetarist persuasion were uniformly optimistic. Milton Friedman's response to the relevant question was

The best evidence is from the prior experience of the U.K. and other countries. As I read that experience . . . I conclude that (a) only a modest reduction in output and employment will be a side effect of reducing inflation to single figures by 1982 and (b) the effect on investment and the potential for future growth will be highly favourable. ${ }^{30}$

In his written submission, David Laidler noted, albeit cautiously, The experience of 1975 onwards does suggest that one might expect a reduction of five percentage points in the inflation rate to be yielded, as a first round effect, by a one percentage point increase in unemployment, but I would not stake much on the quantitative precision of this, or any other such estimate. ${ }^{31}$

Patrick Minford began his written evidence by asserting, The overwhelming problem we face in the U.K. economy is that of breaking, once and for all, the inflation psychology. ... The simulations of our model

28. Monetary Policy, Third Report from the House of Commons Treasury and Civil Service Committee, vol. 2: Minutes of Evidence, sess. 1980-81 (HMSO, 1981), p. 212.

29. Ibid.

30. Memorandum by Professor M. Friedman, in Memoranda on Monetary Policy, p. 61 .

31. Memorandum by Professor D. E. W. Laidler, in Memoranda on Monetary Policy, p. 51 . 
suggest that on the assumption that policies are properly understood when they are announced and implemented, the disturbance to output and employment from reduction in the money supply and in the PSBR would be minimal. ${ }^{32}$

THE TREASURY MODEL AND ECONOMETRIC EVIDENCE

How do the rise in unemployment and the slump in output that have accompanied the undoubted success in bringing down inflation compare with what might have been expected on the basis of past evidence and international experience? Is it consistent with whatever trade-off between inflation and output was perceived by the authorities, for example? And does recent econometric evidence reveal anything about the tradeoff?

A central role in the design of macroeconomic policy in the United Kingdom is played by the Treasury's large macroeconometric model, which is used to produce short-term forecasts and to predict the effects of policy actions on the economy. Since 1975 when an act of Parliament so mandated, the parameters of this model and details of its forecasts (at budget time and in the autumn) are made publicly available and show that, when the MTFS was launched, it included an augmented Phillips curve as the principal determinant of the relation between unemployment and inflation. (The model has subsequently been changed ex post as we discuss below.)

The model thus had an unemployment rate associated with stable inflation and generated changes in steady-state inflation as unemployment varied around this "natural rate." In such a model the impact of these temporary fluctuations of unemployment is determined by the long-run coefficient on unemployment in the Phillips curve itself and the mean lags of the processes averaging past prices in the Phillips curve and averaging past costs in the price-markup equations. The values for these key parameters for two successive versions of the Treasury model are shown in the first and second rows of table $13 .{ }^{33}$

32. Memorandum by Professor A. P. Minford, in Memoranda on Monetary Policy, pp. 131, 142. The model of which Minford speaks is the Liverpool Macroeconomic Research Group model. For details see, for example, A. P. L. Minford, "A Rational Expectations Model of the U.K. under Fixed and Floating Exchange Rates," in Karl Brunner and Allan H. Meltzer, eds., The State of Macroeconomics, Carnegie-Rochester Conference Series on Public Policy, vol. 12 (Amsterdam: North-Holland, 1980), pp. 293-355.

33. Because the Phillips curve is nonlinear, its slope depends on the level of unemployment. 
Table 13. Unemployment Costs of Reducing Steady-State Inflationthe "Sacrifice Ratio"

\begin{tabular}{lllll}
\hline & & \multicolumn{2}{c}{ Determinants of sacrifice ratio } \\
\cline { 3 - 5 } Model & $\begin{array}{c}\text { Sacrifice } \\
\text { ratio }^{\mathrm{a}}\end{array}$ & $\begin{array}{l}\text { Slope of } \\
\text { Phillips } \\
\text { curve }^{\mathrm{b}}\end{array}$ & $\begin{array}{c}\text { ML1, } \\
\text { years }\end{array}$ & $\begin{array}{c}\text { ML2, } \\
\text { years }^{\mathrm{d}}\end{array}$ \\
\hline Treasury model & & & & \\
1978 & $0.90 U$ & $2.50 / U$ & 1.50 & 0.75 \\
1979 & $0.34 U$ & $3.75 / U$ & 0.65 & 0.65 \\
1980 & 2.50 & n.a. & n.a. & n.a. \\
Recent econometric & & & & \\
evidence & & & & \\
GJL, 1982 & $0.81^{\mathrm{e}}$ & 2.18 & 1.09 & 0.67 \\
GJL, 1983 & 0.78 & 0.41 & -0.01 & 0.33 \\
GLS, 1983 & $0.21 U^{\mathrm{e}}$ & $2.01 / U$ & -0.01 & 0.45 \\
\hline
\end{tabular}

Sources: Treasury model, 1978 and 1979 versions-Marcus H. Miller, "The Unemployment Costs of Changing Steady State Inflation" (University of Warwick, 1979); 1980 version-Monetary Policy Report, Third Report from the House of Commons Treasury and Civil Service Committee, sess. 1980-81 (HMSO, 1981); recent evidence, GJL, 1982-D. Grubb, R. Jackman, and R. Layard, "Causes of the Current Stagflation," Review of Economic Studies, vol. 49, no. 159 (1982), pp. 707-30; GJL, 1983-Dennis Grubb, Richard Jackman, and Richard Layard, "Wage Rigidity and Unemployment in OECD Countries," European Economic Review, vol. 21 (March-April 1983), pp. 1139; and GLS, 1983-D. Grubb, R. Layard, and J. Symons, "Wage, Unemployment and Income Policy," Discussion Paper 168 (London School of Economics, Centre for Labour Economics, July 1983).

n.a. Not available.

a. Costs shown are the point-years of unemployment required to reduce steady-state inflation by one percentage point; this ratio is similar to the concept termed the sacrifice ratio by Gordon and King. This ratio is calculated as the sum of the mean lags (third and fourth columns) divided by the long-run Phillips curve (second column). See Robert J. Gordon and Stephen R. King, "The Output Cost of Disinflation in Traditional and Vector Autoregressive Models," $B P E A, 1: 1982$, pp. 205-42. The $U$ is the unemployment rate measured in percentage points.

b. Absolute value of the long-run coefficient on unemployment in the Phillips curve for wage inflation.

c. Mean lag of the process averaging price changes in the Phillips curve.

d. Mean lag of the process averaging wage changes in determining price changes.

e. Authors' calculations based on coefficients reported in sources cited.

The point-years of unemployment required to reduce steady-state inflation by 1 percentage point (which we refer to as the "sacrifice ratio" by analogy with Gordon and King, who use the term to measure the output cost of disinflation) are shown in the first column of the table both for the Treasury model and for recent Phillips curve equations fitted to data on the United Kingdom (and to data on OECD countries besides the United Kingdom) from 1957 to $1980 .{ }^{34}$

The cost to unemployment of reducing inflation shown in the first row of table 13 is obviously very high: for unemployment of about 6 percent the sacrifice ratio is 5.4, and this doubles if the unemployment level doubles. Such calculations are clearly in direct contradiction to the optimism expressed by the monetarists, who argued that a determined

34. Robert J. Gordon and Stephen R. King, "The Output Cost of Disinflation in Traditional and Vector Autoregressive Models," BPEA, 1:1982, pp. 205-42. 
monetary policy would reduce inflation without much cost. ${ }^{35}$ In the second row, however, the sacrifice ratio has been reduced by almost two-thirds (partly by an increase in the assumed effect of unemployment and partly by a shortening of the lags) and stands at 2.0 for unemployment at 6 percent. Treasury evidence submitted to the House of Commons Committee inquiry on monetary policy is consistent with this as shown in the third row.

It is important to note that, although many parameters of the Treasury model are estimated econometrically from time-series data on the economy of the United Kingdom, many are imposed; and this was true of the parameters in the Phillips curve itself, which is hardly surprising given the failure of macroeconomic modelers to find robust econometric specifications of the wage-price behavior in the United Kingdom at the time. In the last three rows of table 13 we therefore consider briefly the implications of some recent econometric work by the Centre for Labour Economics, London School of Economics, on inflation in OECD countries based on annual data for 1957-80. The parameters estimated imply sacrifice ratios for the United Kingdom that are less than that incorporated in the Treasury model of 1979 or 1980 (see the first column).

The studies shown in the last two rows in the table, in particular, suggest that for the United Kingdom, unlike the United States, there is very little "nominal inertia" in the wage-price mechanism. ${ }^{36}$ The fact that these same studies also report $t$-ratios of below 2.0 for the estimated coefficients on unemployment (or its log) must also warn one against taking these low point estimates of the sacrifice ratios too seriously-for as the coefficient on unemployment tends to move toward zero, the sacrifice ratio tends to approach infinity!

35. Thus the sacrifice ratio implicit in what Laidler said by way of evidence is 0.20 (one-fifth percentage point of unemployment for one year to reduce inflation by 1 percentage point). The U.S. evidence at the time indicated that, taking an average of econometric models, the sacrifice ratio for its economy was 3.3. See Arthur M. Okun, "Efficient Disinflationary Policies," American Economic Review, vol. 68 (May 1978, Papers and Proceedings, 1977), pp. 348-62.

36. In other words, the sum of the mean lags is small. Note that the tiny negative value shown for the mean lag in the wage equation reflects the marginal instability of the estimated wage equation, so that transitory fluctuations of unemployment would generate explosive movements of inflation if it were not for the one-quarter lag in the price equation. Estimates for other countries, including West Germany and Japan, imply the same instability. See Dennis Grubb, Richard Jackman, and Richard Layard, "Wage Rigidity and Unemployment in OECD Countries," European Economic Review, vol. 21 (March-April 1983), pp. 11-39. 
What has actually transpired since 1979 is summarized in table 11. The cumulated increase in unemployment point-years has been 20.2 and the rate of inflation has fallen by 8.8 percent, a ratio of 2.3 . As a measure of the theoretical sacrifice ratio, however, this is doubtless biased downward in two ways. ${ }^{37}$ First, it takes the reduction in actual inflation rather than the reduction in "core" or steady-state inflation; second, and even more serious, it assumes that all the unemployment sacrifices are included, but a glance at the projections for unemployment made by the government in forecasting future government expenditures or social security benefits is enough to dispel any such notion. ${ }^{38}$

How can one reconcile the high observed unemployment rateswhich prima facie imply sacrifice ratios above the 2.5 level built into the Treasury model of 1980-with the empirical findings which imply a lower sacrifice ratio (basically because of low nominal inertia)? The answer is to treat a large part of the rise in unemployment in the past two or three years not as a cost of reducing inflation but as a rise in the natural rate.

This seems to be the conclusion that the study in the last row of table 13 reaches, as the authors of that study summarize in their findings:

The unemployment-inflation trade-off is still alive and well. If the wage equation is estimated with log unemployment as a regressor it forecasts recent changes in inflation quite well. The NAIRU [non-accelerating inflation rate of unemployment] has increased. This is partly due to changes in productivity growth but partly to shifts in the $\mathrm{u} / \mathrm{v}$ [unemployment/vacancies] curve. In Britain this shift does not reflect a worsening mismatch between the supply and demand of labour and must reflect changes in willingness to work..$^{39}$

The authors affirm later that

We see the fundamental medium-term problem as being that the NAIRU is high. And in the medium term it is the NAIRU that determines the level of unemployment. ${ }^{40}$

In the next section therefore we consider several of the economic determinants of the natural rate (NAIRU) to see if they support the

37. As emphasized by Jeffrey Sachs in his comments on this paper.

38. See, for example, The Government's Expenditure Plans 1983-84 to 1985-86, presented to Parliament by the chancellor of the exchequer, Cmnd. 8789, vol. 2 (HMSO, $1983)$, p. 65 , in which unemployment of more than 3 million persons is estimated up to 1985-86.

39. D. Grubb, R. Layard, and J. Symons, "Wage, Unemployment and Income Policy," Discussion Paper 168 (London School of Economics, Centre for Labour Economics, July 1983). The italics are added for emphasis by the authors. The notion of willingness to work used here appears to refer to behavior of unions rather than to that of individuals.

40. Ibid., p. 1. 
gloomy conclusion drawn by these authors-that in the absence of an incomes policy, current levels of unemployment are a necessary concomitant of stable inflation.

Our discussion of the econometric evidence would be seriously incomplete without reference to the work inspired by Dennis Sargan, who models wage determination as "error-correction behavior" by unions that attempt (by raising money wages) to get real wages back to some desired path. This leads to the inclusion of both the lagged real consumption wage and a time trend in the wage equation (discrepancies between which might explain rising unemployment at low levels of inflation).

In a paper by Sargan that used quarterly data on the United Kingdom to examine the interaction among wages, earnings, and prices-with the warning that "the estimated models have been found to verge on instability so that changes in exogenous variables may produce large fluctuations in the price level" - - he notes that real wages and expected price inflation are substitutes in the explanation of wage increases..$^{41}$ The implication of including lagged real wages in the conventional Phillips curve and omitting the inflation rate is that one has a Phillips relation that is not vertical in the long run, as Sargan points out. ${ }^{42} \mathrm{He}$ also found that unemployment has little effect on wages and used a variable for strikes instead as a surrogate measure of worker-trade union militancy.

On reestimating its econometric model in 1983, the National Institute of Economic and Social Research reports that it now finds significant unemployment effects on the rate of wage inflation in an equation that includes the lagged consumption wage, a time trend, and a coefficient of less than unity on a moving average of inflation. ${ }^{43}$

If the time trend were to be substantially in excess of the path for real consumption wage, such an equation would in principle account for the rise in unemployment (as the consequence of real wage pressure by unions whose trend targets for real wages exceed what is feasible). But the trend of 2.3 percent a year included in their equation is not much higher than the 1.7 percent annual rise in real earnings per capita

41. J. D. Sargan, “A Model of Wage-Price Inflation," Review of Economic Studies, vol. 47 (January 1980), p. 102.

42. Ibid., p. 108. Hence one cannot talk of NAIRU (a unique stable inflation level of unemployment) but only the low inflation rate of unemployment.

43. See Simon Brooks and Brian Henry, "Reestimation of the National Institute Model," National Institute Economic Review, no. 103 (February 1983), pp. 67-70. 
(according to the institute's definitions of this variable) over the 1979 to 1982 period;44 so that the phenomenon does not appear to explain the rise in unemployment over the period..$^{45}$

In a forthcoming paper by S. Wren-Lewis, Sargan's error-correction interpretation of the determination of wage-earnings increases is adopted. ${ }^{46}$ Grubb reports: "This and similar equations estimated by Wren-Lewis are the basis of the current wage equation in the Treasury economic forecasting model for the U.K. economy." ${ }_{47}$ But in Wren-Lewis's formulation, as in the current Treasury model, it is no longer unemployment but output that appears in the wage equation. For the Treasury it appears that the recent rise in unemployment is not to be interpreted as a rise in the natural rate, which must be tolerated to check inflation: the course of unemployment per se is not relevant to the behavior of inflation!

In the next section we consider the various conventional determinants of the natural rate to see how they have changed over the recent past.

\section{THE NATURAL RATE OF UNEMPLOYMENT ${ }^{48}$}

If there has been a large increase in the natural rate of unemployment since 1979, and if this increase in the natural rate is independent of the increase in actual unemployment, estimates of the cost to unemployment and output of reducing inflation will have to be revised downward.

The natural rate of unemployment is often identified with equilibrium frictional unemployment reflecting search, geographic or occupational mismatch between unemployment and unfilled vacancies, demographic factors, and so on. According to this definition it is almost impossible to make the case that much of the increase in actual unemployment reflects an increase in the natural rate. As pointed out by Metcalf and Richardson, changes in the age and sex composition of the population have affected the natural rate favorably in the past ten years, and the geographic and

44. Ibid., p. 67.

45. Specifically, the real earnings gap of about 2.5 percent for this period implies a rise of about 1.5 points in the low-inflation unemployment rate in the institute's model. We discuss the "real producer-wage gap" theory of Sachs below.

46. S. Wren-Lewis, "A Model of the Behaviour of Private Sector Earnings from 1966 to 1980," Oxford Economic Papers (forthcoming).

47. David Grubb, "Lagged Output in the Wage Equation," Discussion Paper 161 (London School of Economics, Centre for Labour Economics, June 1983).

48. Interpreted to include the unemployment rate associated with low inflation if there is no natural rate. 
occupational mismatch between vacant jobs and unemployed workers does not appear to have increased. ${ }^{49}$

Most discussions of the natural rate for the United Kingdom include what may be termed union power-induced classical unemployment in the natural rate. The argument is as follows. If higher unemployment does not have an appreciable depressing effect on the rate of change of the real consumption wage in the unionized sector, and if inflation either has no effect on the real consumption wage (or only a temporary effect, to the extent that it is unanticipated, with full catching up in the longer run), an increase in union power will, by raising the union real wage, reduce the demand for labor and cause a loss of employment in the unionized sector. This presupposes that the effective demand function for labor in the unionized sector can be represented by a downwardsloping schedule for the marginal revenue product of labor. Whether such an increase in union power and in the union-nonunion markup raises the economy-wide unemployment rate depends on what happens in the nonunionized sectors of the economy. Those who lose jobs in the unionized sector as a result of the increase in the union markup either become unemployed or take a job in the nonunionized sectors in which the real wage, which is competitively determined, will fall. The choice between unemployment and employment in the nonunion sectors depends on the relation between unemployment compensation and the nonunion wage. To the extent that unions feel a concern for those among their members who become unemployed, an increase in unemployment benefits may weaken restraint and lead to an increase in the union real wage.

One can obtain a sense of the likely significance of the argument that much, if not all, of the decline in employment is classical by considering the behavior of indexes of trade union power, changes in unit-labor costs or in the wage gap, and changes in the "replacement ratio"- - the ratio of income when unemployed to income when employed.

Trade Union Power. Table 14 shows some measures of trade union power and activity since 1970. "Trade union density" is measured by dividing union membership by the number of persons employed plus the number unemployed, excluding school leavers. By including the unemployed in the denominator, this may overstate union power in an upswing

49. David Metcalf and Ray Richardson, "Labour," in A. R. Prest and D. J. Coppock, eds., U.K. Economy: A Manual of Applied Economics, 9th ed. (London: Weidenfeld and Nicholson, 1983), pp. 262-63. 
Table 14. Trade Union Membership and Industrial Disputes, 1970-82

\begin{tabular}{|c|c|c|c|c|}
\hline \multirow[b]{2}{*}{ Year } & \multirow[b]{2}{*}{$\begin{array}{c}\text { Union } \\
\text { density } \\
\text { (percent })^{\mathrm{a}}\end{array}$} & \multirow{2}{*}{$\begin{array}{c}\text { Corrected } \\
\text { union } \\
\text { density } \\
\text { (percent) }\end{array}$} & \multicolumn{2}{|c|}{ Industrial disputes } \\
\hline & & & $\begin{array}{l}\text { Number } \\
\text { of stop- } \\
\text { pages }\end{array}$ & $\begin{array}{l}\text { Working } \\
\text { days lost }\end{array}$ \\
\hline 1970 & 48.5 & 49.8 & 3,906 & 10,980 \\
\hline 1971 & 48.6 & 50.3 & 2,228 & 13,551 \\
\hline 1972 & 49.4 & 51.3 & 2,497 & 23,909 \\
\hline 1973 & 49.2 & 50.5 & 2,873 & 7,197 \\
\hline 1974 & 50.3 & 51.6 & 2,922 & 14,750 \\
\hline 1975 & 51.6 & 53.7 & 2,282 & 6,012 \\
\hline 1976 & 52.1 & 55.0 & 2,016 & 3,284 \\
\hline 1977 & 53.7 & 56.8 & 2,703 & 10,142 \\
\hline 1978 & 54.4 & 57.6 & 2,471 & 9,405 \\
\hline 1979 & 55.3 & 58.2 & 2,080 & 29,474 \\
\hline 1980 & 53.1 & 56.7 & 1,330 & 11,964 \\
\hline 1981 & 50.6 & 56.2 & 1,338 & 4,266 \\
\hline 1982 & n.a. & n.a. & 1,454 & 5,256 \\
\hline
\end{tabular}

Sources: Union membership and industrial disputes are from Employment Gazette, vol. 89 (January 1981), pp. 26-28, and vol. 91 (June 1983), table 4.2, and previous issues; employment and unemployment are from Economic Trends, no. 358 (August 1983), p. 36, and previous issues.

n.a. Not available.

a. Union membership divided by employees in employment and unemployment, excluding school leavers.

b. Trade union membership divided by number of persons employed.

and understate it in a downswing, as the unemployed typically cease to be counted as union members. "Corrected trade union density" divides membership by persons employed only. It is not clear which measure is superior; some believe that unemployment weakens unions. ${ }^{50}$

The trade union density figures show a sizable rise between 1973 and 1979 (6.1 percentage points by the uncorrected measure and 7.7 percentage points by the corrected one). The uncorrected measure then declines rapidly toward its level in the early 1970 s as unemployment dramatically increases, and the corrected measure also shows a drop of 2 percentage points from 1979 to 1981 . To help interpret these aggregate figures, it should be noted that about 50 percent of the increase in union membership between 1969 and 1979 occurred in the public sector, especially in health services, local government, and education. Another 20 percent occurred in engineering and metals. Between 1968

50. Both measures suffer from potentially serious endogeneity bias as indexes of union power because powerful unions are likely to attract many members. The same endogeneity problems limit the usefulness of the union-nonunion markup as an index of union power; the markup is the outcome of a process in which union power is but one of the exogenous inputs. 
and 1979 union density in manufacturing increased from 49.9 percent to 69.8 percent, both manual workers (up from 62.0 percent to 80.3 percent) and white-collar workers (up from 15.4 percent to 43.7 percent). Other sectors such as construction and private services saw a much smaller increase from a much smaller base.

Both measures point to an increase in union power until 1979. Since then the fortunes of organized labor have waned very sharply. Only if union power affects employment with a long lag can one reasonably attribute part of the post-1979 increase in unemployment to the pre-1979 increase in union power. Empirical work by Nickell and Andrews estimates that union power reduced employment by 400,000 since World War II by raising real wages. While by no means insignificant, this is modest alongside the loss of 2 million jobs between 1979 and 1982. ${ }^{51}$

Dennis Sargan, in the study referred to above, measures "workertrade union" militancy by a moving average of working days lost in strikes in the previous three years. In table 14 that measure shows a pronounced peak in 1979, followed by a return to more normal levels thereafter. The number of strikes, also shown in the table, declined from 1977 to 1980 to the lowest level since 1942, and has risen only a little since then. This evidence suggests a decline in union militancy from its recent peak, though whether this is merely cyclical remains to be seen.

Labor Costs. Evidence of an increase in real marginal labor costs in excess of the increase in labor's marginal revenue product at a constant flow of person-hour input would support the view that part of the employment decline simply reflects labor pricing itself out of the market. Jeffrey Sachs has argued that such a development, reflected in what he calls the wage gap, is central in explaining the evolution of both inflation and unemployment. ${ }^{52}$ The wage gap is measured as the ratio of the normalized labor share in value added relative to the average normalized share in 1965-69, where the normalization is used to correct for cyclical effects on observed shares.

The wage-gap data for manufacturing in the United Kingdom are shown in table 15, calculated on the same basis as Sachs proposes. The

51. S. J. Nickell and M. Andrews, "Unions, Real Wages, and Employment in Britain, 1951-79," Discussion Paper 152 (London School of Economics, Centre for Labour Economics, April 1983).

52. Jeffrey D. Sachs, "Real Wages and Unemployment in the OECD Countries," BPEA, $1: 1983$, pp. 255-89. 
Table 15. Labor Share and Normalized Labor Share of GDP, 1973-82

\begin{tabular}{|c|c|c|c|c|c|c|}
\hline \multirow[b]{3}{*}{ Year } & \multicolumn{2}{|c|}{ Total economy } & & & & \\
\hline & \multirow[b]{2}{*}{$\begin{array}{c}\text { Uncor- } \\
\text { rected } \\
\text { labor } \\
\text { share }^{\mathrm{a}}\end{array}$} & \multirow{2}{*}{$\begin{array}{l}\text { Normal- } \\
\text { ized } \\
\text { labor } \\
\text { share, } \\
\text { exclud- } \\
\text { ing self- } \\
\text { employed }\end{array}$} & \multicolumn{2}{|c|}{$\begin{array}{c}\text { Entire economy, } \\
\text { excluding oil and gas }\end{array}$} & \multicolumn{2}{|c|}{ Manufacturing sector } \\
\hline & & & $\begin{array}{c}\text { Uncor- } \\
\text { rected } \\
\text { labor } \\
\text { share }^{\mathrm{a}}\end{array}$ & $\begin{array}{c}\text { Normal- } \\
\text { ized } \\
\text { labor } \\
\text { share }^{\mathrm{b}}\end{array}$ & $\begin{array}{l}\text { Uncor- } \\
\text { rected } \\
\text { labor } \\
\text { share }^{\mathrm{a}}\end{array}$ & $\begin{array}{c}\text { Normal- } \\
\text { ized } \\
\text { labor } \\
\text { share }^{\mathrm{b}}\end{array}$ \\
\hline 1973 & 66.9 & 66.9 & 66.9 & 66.9 & 71.9 & 71.9 \\
\hline 1974 & 70.2 & 68.2 & 70.2 & 68.6 & 78.6 & 76.8 \\
\hline 1975 & 72.6 & 68.8 & 72.6 & 69.6 & 81.1 & 76.5 \\
\hline 1976 & 70.8 & 68.2 & 71.2 & 69.4 & 79.7 & 78.6 \\
\hline 1977 & 67.2 & 65.8 & 68.3 & 67.3 & 73.6 & 73.1 \\
\hline 1978 & 66.7 & 66.4 & 70.0 & 70.0 & 72.8 & 72.4 \\
\hline 1979 & 67.8 & 67.8 & 70.1 & 70.1 & 77.4 & 77.4 \\
\hline 1980 & 69.1 & 67.3 & 72.3 & 70.7 & 79.2 & 75.3 \\
\hline 1981 & 69.2 & 67.6 & 73.2 & 71.8 & 81.3 & 79.2 \\
\hline 1982 & 68.1 & 67.9 & n.a. & n.a. & n.a. & n.a. \\
\hline
\end{tabular}

Sources: Uncorrected labor share, employment, and GDP are from Economic Trends, no. 358 (August 1983), pp. 6, 14, 36, and previous issues; entire economy, excluding oil and gas, is from National Income and Expenditures (HMSO, 1983), table 31; and normalized shares are based on authors' calculations.

n.a. Not available.

a. Ratio of employment income to GDP (income based), with employment income defined as wages, salaries, military pay, and employers' contributions.

b. Uncorrected share multiplied by the ratio of measured productivity to trend productivity, where trend productivity is measured by the method suggested in Jeffrey D. Sachs, "Real Wages and Unemployment in the OECD Countries," BPEA, 1:1983, pp. 255-89.

normalized labor share for manufacturing rises by almost 7 points from 1978 to 1981; the rise, while substantial, is much less than the increase of 11 points reported by Sachs. This illustrates the great sensitivity of these calculations to the addition of one year's data. Adding productivity data for 1982 raises the assumed post-1979 trend from 0.8 percent to 1.2 percent a year, using annual data, where this "trend" is measured as the average of the actual productivity growth from 1973 to 1979 and actual growth after 1979.

The normalized labor share for the entire economy calculated on the same basis, however (second column of the table), shows hardly any change from 1973, and no change since 1979. This constancy of share, in surprising contrast to the figures for manufacturing, masks a shift in nonlabor income to nonoil and nongas rents. When the oil and gas are excluded, as in the fourth column, a distinct rise in the normalized labor 
share is observable, though it is much less marked than for manufacturing.

The substantial increase in labor's share in the manufacturing sector, whether normalized or not, is consistent with the view that real labor cost-push in the manufacturing sector has contributed to the decline of employment. It is also consistent with the view that real wages rose endogenously through a combination of nominal wage inertia and contractionary demand shocks. Between 1975 and 1981 nominal wages and salaries per unit of output and nominal unit-labor costs rose 10 percent more in manufacturing than in the economy as a whole. ${ }^{53}$ While the output prices of certain internationally exposed sectors of manufacturing (such as steel, metal manufacturing, electrical engineering, chemicals and allied industries, and instrument engineering) have risen much less than the overall GDP deflator since the pound sterling began its upward climb, this is not true for manufacturing as a whole. ${ }^{54}$

For the entire economy it appears that labor has managed to resist the impact of rising oil and gas rents on its share, with the result that this has been taken out of profits and rents elsewhere in the economy. The fact that real product wage pressure has been stronger in the United Kingdom, an oil-producing country, than elsewhere is probably because unions have not realized the necessity, despite rising oil revenues, of reducing unit-labor costs in line with overseas competitors. The government has not helped in this. It first encouraged widespread indexation in 1973-74 and then adopted a narrow cashflow rather than a permanent income view when planning tax cuts after the second rise in oil prices.

Unemployment Benefits. On the labor supply side, higher unemployment benefits could increase the natural rate of unemployment by encouraging longer search, and thus lengthening the duration of unemployment or simply by making it possible for workers to leave the effective labor force and choose a life on the dole and perhaps in the "black economy." Although registered as unemployed, these persons no longer search for employment. This voluntary unemployment choice presumably depends on the replacement ratio, which is the ratio of aftertax income when employed to income after tax and work-related expenses when employed. This replacement ratio varies widely for different income levels and family types, and is summarized by the average for

53. Economic Trends, no. 358 (August 1983), p. 40.

54. United Kingdom, Central Statistical Office, Monthly Digest of Statistics, no. 451 (July 1983), p. 153, table 18-1. 
different family types displayed below. ${ }^{55}$ There is no evidence of a rise in the replacement ratio that could account for higher unemployment as a supply-side phenomenon.

Replacement ratio

(average)

$\begin{array}{ll}1960-64 & 0.44 \\ 1965-69 & 0.52 \\ 1970-74 & 0.50 \\ 1975-79 & 0.49 \\ 1980-82 & 0.48\end{array}$

SUMMAR Y

The evidence suggests that, if the economy were stimulated to eliminate Keynesian deficient effective demand unemployment, there would remain a margin, possibly substantial, of classical unemployment over and above the frictional natural rate. Real labor costs, especially in manufacturing, are above their equilibrium levels seen in 1979, for example.

The evidence also suggests that an inflationary spiral can quickly erupt when a conflict exists between the real incomes available and that for which groups are bargaining. But it does not support the view that the solution to this process is to leave unemployment at its present level or let it climb higher.

For one thing, several studies have found that the level of unemployment itself was not a significant explanatory variable in the wage-earnings equation. ${ }^{56}$ For another, a policy of reducing national income and employment (and it is important to note that the number of jobs in Britain fell absolutely and continuously from 1979 to early 1983) seems unlikely to solve conflicts whose basis is claims for real income. ${ }^{57}$ Indeed, the massive rise in unemployment since 1979 and the costs of this to the exchequer have, given the desire to reduce the deficit, led to increases in the burden of personal taxation that may have exacerbated the inflationary spiral by holding down real after-tax income.

55. Based on David Metcalf, Stephen Nickell, and Nicos Floros, "Still Searching for an Explanation of Unemployment in Inter-War Britain," Discussion Paper 71 (London School of Economics, Centre for Labour Economics, September 1980).

56. See Sargan, "A Model of Wage-Price Inflation"; Wren-Lewis, "A Model of the Behaviour of Private Sector Earnings"; and "H.M. Treasury Macroeconomic Model, 1982"' (London: H. M. Treasury, 1982).

57. Economic Trends, no. 358 (August 1983), p. 36. 
While supporting the search for a viable incomes policy that would reduce the natural rate, we are convinced that there is ample room for noninflationary expansion even in its absence. The limits to which demand management may operate without rekindling inflation are, to be sure, dependent on the institutional structure of labor markets and the behavior of trade unions in particular. ${ }^{58}$ But since 1980 the trade unions have become weaker than at any time during the previous decade. And the government can avoid actions that helped to stimulate inflation in its first period of office, such as the 8 percent rise in indirect taxation in June 1979 and the 25 percent increase in public sector salaries from 1979 to 1980 .

\section{A Productivity Phoenix?}

Improved productivity is one of the main benefits claimed for the policies adopted by the Thatcher government. Supply-side policies, according to this view, have created conditions that permit and encourage improvements in the efficiency with which existing labor and capital resources are utilized. These policies include legislation restricting the power of organized labor, some privatization of publicly owned industries, and a reduction in marginal and average direct tax rates for those at the upper end of the income distribution. Some observers also emphasize a growing awareness, especially in the publicly owned industries, that this government is unwilling to bail out or subsidize chronic loss-makers on the same scale as its predecessors. The recession itself is viewed in rather Darwinian terms as speeding up the transition to a higher norm of efficiency through the liquidation of weak and inefficient firms. The resources thus freed will in due course be absorbed into the new high productivity uses-a phoenix will arise from the ashes.

The record of labor productivity is shown in table 16 for the total economy and for the manufacturing sector. The reason for isolating manufacturing is that the best data on productivity are for this sector,

58. As Keynes himself recognized in The General Theory of Employment, Interest, and Money (Harcourt, Brace, 1936), chap. 2, p. 8. Robert Skidelsky, who is currently writing a biography of Keynes at the University of Warwick, has suggested that, of the 16 percent unemployment observed during the depression, Keynes would have treated almost half as "natural.", 
Table 16. Output, Employment, and Labor Productivity, 1970 to 1983:1

\begin{tabular}{|c|c|c|c|c|c|c|}
\hline \multirow[b]{2}{*}{$\begin{array}{c}\text { Year } \\
\text { or } \\
\text { Quarter }\end{array}$} & \multicolumn{5}{|c|}{ Manufacturing sector } & \multirow[b]{2}{*}{$\begin{array}{c}\text { Entire } \\
\text { economy, } \\
\text { growth in } \\
\text { output per } \\
\text { person } \\
\text { (percent) }^{\mathrm{c}}\end{array}$} \\
\hline & $\begin{array}{c}\text { Output } \\
\text { (index, } \\
1975=100)\end{array}$ & $\begin{array}{c}\text { Employ- } \\
\text { ment } \\
\text { (index } \\
1975=100)\end{array}$ & $\begin{array}{l}\text { Growth in } \\
\text { output per } \\
\text { person } \\
\text { (percent) }^{\mathrm{a}}\end{array}$ & $\begin{array}{c}\text { Growth } \\
\text { in output } \\
\text { per person } \\
\text { hour } \\
{\text { (percent })^{\mathrm{a}}}\end{array}$ & $\begin{array}{c}\text { Growth } \\
\text { in output } \\
\text { per person } \\
\text { hour } \\
\text { utilization } \\
\text { corrected } \\
{\text { (percent })^{\mathrm{a}, \mathrm{b}}}\end{array}$ & \\
\hline 1970 & 98.4 & 111.3 & 0.6 & n.a. & n.a. & 2.2 \\
\hline 1971 & 97.3 & 107.5 & 2.3 & 4.1 & n.a. & 3.1 \\
\hline 1972 & 99.6 & 103.8 & 6.0 & 6.3 & n.a. & 2.9 \\
\hline 1973 & 108.8 & 104.3 & 8.6 & 7.1 & 2.7 & 3.5 \\
\hline 1974 & 107.5 & 104.6 & -1.4 & 0.6 & 2.2 & -1.9 \\
\hline 1975 & 100.0 & 100.0 & -2.7 & -1.9 & 1.5 & -1.4 \\
\hline 1976 & 102.0 & 96.9 & 5.3 & 5.2 & 3.1 & 2.1 \\
\hline 1977 & 103.9 & 97.2 & 1.6 & 0.9 & -1.3 & 1.6 \\
\hline 1978 & 104.5 & 96.8 & 0.8 & 1.0 & 1.1 & 1.7 \\
\hline 1979 & 104.6 & 95.8 & 1.4 & 1.4 & 2.1 & 0.2 \\
\hline 1980 & 95.0 & 90.3 & -3.8 & -1.3 & 2.9 & -2.0 \\
\hline 1981 & 89.0 & 81.6 & 3.7 & 4.9 & 7.8 & 1.0 \\
\hline 1982 & 88.4 & 77.1 & 5.1 & 3.9 & 1.4 & 3.3 \\
\hline 1980:1 & 100.8 & 93.7 & -8.8 & -6.4 & -5.3 & -2.2 \\
\hline 2 & 97.6 & 91.9 & -4.8 & 0.0 & 10.6 & -4.0 \\
\hline 3 & 93.3 & 89.3 & -6.3 & -0.4 & 10.6 & -2.9 \\
\hline 4 & 88.7 & 86.4 & -7.1 & -1.1 & 9.2 & -1.1 \\
\hline 1981:1 & 87.9 & 84.1 & 7.6 & 9.3 & 16.2 & 3.0 \\
\hline 2 & 88.3 & 82.1 & 12.4 & 7.9 & -1.3 & 3.0 \\
\hline 3 & 89.8 & 80.6 & 14.9 & 10.4 & 3.0 & 5.3 \\
\hline 4 & 89.8 & 79.6 & 5.1 & 3.5 & 1.8 & 3.3 \\
\hline 1982:1 & 89.5 & 78.6 & 4.0 & 3.2 & 3.9 & 0.4 \\
\hline 2 & 89.0 & 77.7 & 2.1 & 2.8 & -1.0 & 2.9 \\
\hline 3 & 88.1 & 76.5 & 2.5 & 1.7 & -2.8 & 4.0 \\
\hline 4 & 87.0 & 75.4 & 0.3 & -0.7 & 5.5 & 3.2 \\
\hline $1983: 1$ & 88.5 & 73.6 & 18.1 & 18.2 & n.a. & 2.1 \\
\hline
\end{tabular}

Source: Economic Trends, no. 358 (August 1983), pp. 28, 34, and previous issues. The utilization corrected series is from Lionel Mendis and John Muellbauer, "Has There Been a British Productivity Breakthrough? Evidence from an Aggregate Production Function for Manufacturing" (London School of Economics. Centre for Labour Economics, July 1983).

a. Quarterly changes are at annual rates.

b. See text for a description of this series.

c. Annual data for 1973-82 excludes oil and natural gas production.

and most empirical research on the subject covering the recent past deals with manufacturing productivity. ${ }^{59}$ However, the importance of this sector should not be exaggerated, as it appears to be in secular decline

59. For example, see S. G. B. Henry and Simon Wren-Lewis, "Manufacturing Employment and Expected Output,' Discussion Paper 55 (National Institute of Economic 
and now accounts for less than a third of economic activity in the United Kingdom. ${ }^{60}$

It is clear that there was a sizable rise in labor productivity in the last two years, with the improvement more marked in manufacturing than in the economy as a whole. In what follows we first describe these encouraging developments in more detail, while noting that the improvements thus far observed are by no means unprecedented in recent experience in the United Kingdom. We then examine how much of this productivity recovery may simply be in the nature of one-time adjustments rather than a change in the trend growth of productivity. Finally, we look at recent developments and trends observed in the United Kingdom since 1973 and trends before the oil shocks of the 1970s.

THE PRODUCTIVITY BOOM SINCE I980

Since its trough in 1980 output per worker in manufacturing has grown by 10 percent from $1980: 4$ to $1981: 4$ and by 2.2 percent from 1981:4 to 1982:4. A further rise of 4.2 percent occurred in the single quarter of 1983:1. These and parallel data for other measures of productivity in the United Kingdom's economy are summarized in the display below. ${ }^{61}$

\begin{tabular}{lccc} 
& \multicolumn{3}{c}{ Productivity growth (percent) } \\
\cline { 2 - 4 } & $\begin{array}{c}1980: 4- \\
1981: 4\end{array}$ & $\begin{array}{c}1981: 4- \\
1982: 4\end{array}$ & $\begin{array}{c}1983: 1 \\
\text { (at annual } \\
\text { rate) }\end{array}$ \\
$\quad$ Productivity measure & & & \\
Manufacturing & 10.0 & 2.2 & 17.9 \\
$\quad \begin{array}{l}\text { Output per worker } \\
\text { Output per hour }\end{array}$ & 7.8 & 1.7 & 18.3 \\
Entire economy & 3.7 & 2.6 & 2.0 \\
$\quad \begin{array}{l}\text { Output per worker } \\
\text { Output per worker, excluding }\end{array}$ & 3.5 & 2.1 & 2.4
\end{tabular}

Research, 1983); P. S. O'Brien, "Employment: Systematic Econometric Comparisons" (National Institute of Economic and Social Research, March 1983); and Lionel Mendis and John Muellbauer, "Has There Been a British Productivity Breakthrough? Evidence from an Aggregate Production Function for Manufacturing' (London School of Economics, Centre for Labour Economics, July 1983).

60. The manufacturing share of total employment was 28.5 percent in $1981,31.3$ percent in 1979, and 36.4 percent in 1971. Its share in value added was 23.7 percent in 1981, 27.0 percent in 1979, and 31.7 percent in 1971.

61. We are also warned by the Central Statistical Office that since the second half of 
The kind of productivity spurt seen in the past two and a half years is not without precedent in the recent economic history of the United Kingdom. Manufacturing output per worker grew by 15.2 percent between 1966:4 and 1969:1, compared with 16.2 percent between 1980:4 and 1983:1. Manufacturing output per hour grew by 16.6 percent between 1971:1 and 1973:2, compared with 13.3 percent between 1980:4 and 1983:1, as shown in table 16. Between the two cyclical peaks of 1966 and 1973, output per worker in manufacturing grew at an annual rate of 4.4 percent and at 3.2 percent for the entire economy.

The series for output per hour is generally thought to be a better approximation of the nonobservable trend productivity than output per worker because it contains a partial correction for changes in labor utilization rates. Mendis and Muellbauer note that reported changes in hours worked, while providing a reasonable estimate of change in the amount of overtime, were likely to understate or even leave unreported the changes in the amount of "undertime"-hours paid for but not worked. ${ }^{62}$ Reported variations in hours therefore represented samples drawn from a truncated distribution. Correction for this yields their "utilization-corrected" series for labor productivity in manufacturing shown in table 16. This series had its trough in 1980:1, three quarters before the other two series. Rapid growth in the index lasted from 1980:1 until 1981:1 when utilization-corrected productivity was 11.3 percent above its level five quarters earlier. During the six quarters from 1981:2 to $1982: 4$, utilization-corrected productivity only gained another 2.6 percent. The data do not extend into 1983 , so one cannot verify whether the large productivity gain in the other two series is mirrored in the Mendis-Muellbauer index. The Mendis-Muellbauer utilization measure has gained support no doubt from its remarkable similarity to the independently constructed "technological productivity index" of Bennett and Smith-Gavine. This index also dates the productivity leap between 1980:1 and 1981:1 and shows the same relative stagnation since.

1981 the provisional estimates of the employed labor force may have been understating the level of employment, particularly in the service industries. This implies that output per person employed for the entire economy may have been slightly overstated.

62. Mendis and Muellbauer, "Has There Been a Productivity Breakthrough?" See A. J. Bennett and S. A. N. Smith-Gavine, "The Index of Percentage Utilization of Labour: Bulletin to Co-operating Firms," no. 44, February 1983, cited in Mendis and Muellbauer. The index is based on a survey of manufacturing firms and measures the rate of utilization of operatives using production-management concepts of work measurement. 


\section{EMPLOYMENT AND OUTPUT EXPECTATIONS}

Even if the growth of productivity since late 1980 is not without recent precedent, it still appears unusual given the behavior of output and employment. In particular, it is striking that these productivity gains have been achieved when manufacturing output was falling sharply and the entire economy was settling into a growth recession.

Labor productivity usually recovers when the economy recovers, as the counterpart of Okun's law. For cost-minimizing firms that take output as parametric, employment adjustment will make optimal current employment a function of past employment and of current and anticipated future output and future input prices. Expansions (contractions) in output that are perceived as temporary, such as the fluctuations of economic activity in a regular business cycle, will, if employment is more costly to adjust than hours and intensity of work, give rise to increases (reductions) in labor utilization rates and thus in output per worker. If capital utilization rates vary procyclically, this will reinforce the tendency for the covariation of output and employment over the cycle to bear little if any relation to the marginal product of effective labor services, holding constant all other inputs and the state of technology.

Mechanical application of Okun's law would hardly lead one to expect a recovery in productivity when there is no basic recovery in the economy, and the usual time-series regressions, which relate employment to lagged output and employment, greatly underpredict productivity since 1980:4. ${ }^{63}$ If the recovery of productivity from its trough is not to be accounted for by the recovery of the economy, could it not then represent the beginning of a new trend, evidence of a "productivity phoenix"'?

Such an argument is, we believe, not well founded as it takes little account of the way in which changed expectations will alter Okun's law itself. The same anticipatory behavior that generates the cyclical recovery of productivity in an upswing can generate an even quicker recovery of productivity when output is expected to stabilize at recession level.

By late 1980 manufacturers realized that this was no ordinary recession

63. See Henry and Wren-Lewis, "Manufacturing Employment"; O’Brien, "Employment"; and Mendis and Muellbauer, "Has There Been a Productivity Breakthrough?" 
to be followed by a traditional recovery and return to previous high levels of capacity utilization. Industrial confidence indicators, industrial production indicators, and export order books recovered somewhat toward the end of 1980 but did not signal any kind of strong recovery. The government's own output projections, like those made by most domestic nongovernmental forecasters and by the OECD, signaled stagnation followed by low rates of growth. Because there was no point in hoarding labor any longer in anticipation of a strong recovery, labor was promptly shed faster than output fell, with a resulting boost for productivity.

By this interpretation one would need to correct the observed increase in labor productivity for changed output expectations before estimating gains in underlying efficiency. The Mendis-Muellbauer utilization-corrected productivity series is one attempt to do this, and we believe it presents a better measure of the productivity shift that has occurred.

As has been noted, however, Mendis and Muellbauer find a rapid increase in corrected productivity starting in early 1980 . Before concluding that this path accurately represents the new trend, however, one must account for the one-time gains that may have occurred following the contraction of capacity.

\section{THE EFFECT OF SCRAPPING AND CLOSURES}

In the economy as a whole-and especially in manufacturing, where output fell by one-sixth between 1979 and the end of 1982-there has been widespread scrapping of plant and machinery and closure of production units and firms, the rational response if a return to previous levels of capacity utilization is likely to be postponed substantially or indefinitely. Assuming that, on balance, productive capacity gets scrapped and labor laid off in inverse order to its efficiency, the average level of productivity of the surviving capacity will be raised. None of the resources that continue to be employed, however, need to be used more productively than before for this statistical improvement to occur. ${ }^{64}$ Even if production units are shut down temporarily instead of being scrapped permanently, the same productivity increase will be recorded in the short run. Whether there is a real improvement depends on the

64. The simplest model generating this kind of behavior has fixed coefficients between capital and labor and various vintages of capital with different levels of productivity. 
use made of the resources that have been freed by shutting down the least efficient capacity.

Thus far most of these resources have become unemployed and remain so-a transfer from a low to a zero productivity use. To the extent that these resources are in due course reemployed at productivity levels as high as those of the surviving capacity, the higher productivity levels recorded with the surviving capacity can be viewed as permanent. It is difficult to think of good economic reasons for believing labor that previously worked in low-productivity units will be reabsorbed at a higher level of productivity without increased expenditures on capital formation. Even if this were to occur, the question would remain whether a prolonged period of enforced idleness is necessary before factors in low-productivity uses can be transferred to high-productivity uses.

In short, the current productivity record of much of the manufacturing industry in the United Kingdom is like the cricket team that improves its batting average by only playing its better batsmen! As long as the "tailenders" score some runs, however, it would surely be better to let them play even if it does lower the side's batting average. Mendis and Muellbauer concur in the view that the unexplained part of the productivity increase, which they estimate at just over 6 percentage points, is largely due to production being discontinued at the less efficient plants. ${ }^{65}$ This is consistent with the improvement seen in their utilization-corrected productivity index for the period from 1980:1 to 1981:2 when manufacturing output was falling rapidly.

\section{IMPROVING EFFICIENCY}

Since the Tories came to power in 1979 there has been a shift in the balance of industrial bargaining power away from the unions and toward management. This came about partly through legislation restricting union immunities, partly through intentional neglect by the government of the unions as participants in the discussion and design of macroeconomic and industrial policy, and partly because of the unpopularity of organized labor since the 1978-79 "winter of discontent." Further changes along the same lines are expected. To the extent that it was union resistance to the introduction of more efficient work practices

65. Mendis and Muellbauer, "Has There Been a Productivity Breakthrough?" 
rather than managerial ignorance or incompetence that forced the economy to a position well inside the technological production possibility frontier, such a weakening of union veto power will permit an increase in productivity.

It is important that the weakening of union power is a function of the change in the legal and institutional framework rather than merely a reflection of the depressed state of economic activity. If these gains can be made permanent only by keeping the economy at the current, very low level of capacity utilization, the costs are likely to outweigh the benefits. There is considerable empirical evidence, both anecdotal and casual, that not all gains from reducing overmanning, ending restrictive practices, introducing a more flexible use of labor within the enterprise, and the like are "cyclically reversible." For example, labor and capital resources still employed in the British Steel Corporation, British Leyland, and British Airways are being used more productively, and a return to previous levels of inefficiency appears unlikely.

There can be no doubt that there was and is scope for improvement in productivity in many industries in the United Kingdom, even with existing capital and labor resources. ${ }^{66}$ Weakening the ability of organized labor to resist changes in work practices, in the organization of production, and in manning levels may be a necessary condition for achieving some of the potentially available gains in productivity; but it is unlikely to be sufficient. Poor management and lack of cooperation between management and workers are two other reasons for industrial inefficiency in the United Kingdom, and they have not been the focus of any concerted government policies and actions.

\section{COMPARISONS WITH THE PAST}

Whether recent performance constitutes a productivity revolution depends, in part, on the period with which it is compared. The spurt in productivity since 1980 - output per person rose 2.1 percent a year for the entire economy and 4.4 percent a year in manufacturing between 1980 and 1982 - compares favorably with the trend prevailing between the two previous output peaks, 1973 and 1979. However, not only is it

66. See A. D. Smith, D. M. W. N. Hitchens, and S. W. Davies, International Industrial Productivity: A Comparison of Britain, America and Germany, National Institute of Economic and Social Research, Occasional Paper 34 (Cambridge University Press, 1982). 
inappropriate to measure a new trend from the last two or three years, for reasons we have discussed above, but the 1973-79 trend is a poor bench mark because of developments that made productivity growth then unusually slow.

The annual growth rates experienced in the period from the preOPEC peak of 1973 to the pre-Thatcher peak in 1979 were as follows: output per person employed in the entire economy, 0.88 percent; nonoil GDP per person employed, 0.33 percent; output per worker in manufacturing, 0.80 percent; and output per person hour in manufacturing, 1.18 percent ${ }^{67}$ However, the cyclical position of the economy was different in the two final years of the period. The unemployment rate stood at 2.6 percent in 1973 and at 5.1 percent in 1979. Unfilled vacancies stood at 306,700 in 1973 and 241,300 in 1979, and average weekly hours worked by operatives in manufacturing were 3 percent higher in 1973 than in 1979. Even allowing for shifts in the natural rate, there can be little doubt that capacity utilization was higher in 1973 than in 1979.

Equally important, trend fitting between 1973 and 1979 ignores the downward shift in the level of cyclically adjusted productivity that both economic theory and the data suggest occurred between 1973 and 1975 as a result of the unanticipated increase in the real price of energy in 1973-74. A similar but smaller downward step adjustment in productivity appears to have occurred after the second OPEC oil-price shock in 197980. All this suggests that productivity growth between 1973 and 1979 was unusually low and that the period is unrepresentative of underlying trends.

The contrast between the 1973-79 period and the period immediately preceding the first OPEC shock is striking. As already noted, output per person employed rose by an average of 3.2 percent a year in the entire economy from 1966 to 1973 and by 4.4 percent a year in manufacturing over the same period. These are similar to the productivity gains experienced since 1980 .

If productivity growth has returned to pre-OPEC rates, there is a danger that continued contractionary policy would lead to even higher levels of unemployment. On the other hand, combined with a recovery of demand, a productivity boom should help ease the conflict between real wage targets and reality and so relieve the inflationary pressures.

67. Economic Trends, Annual Supplement, 1983 Edition, p. 97; and Economic Trends, no. 358 (August 1983), p. 34. 


\section{Changing the Rules of the Game}

It is widely believed - not least by the government-that the current approach to the design and execution of macroeconomic policy represents a radical departure from conventional post-World War II practice.

In one interpretation the current government is seen as denying any need to use activist demand-management policies to achieve full employment because the self-equilibrating tendencies of the economic system are strong enough and fast enough to make any stabilization policy redundant. In our view such a new classical macroeconomics perspective emphasizing simple (preferably fixed or open-loop) policy rules for the government to enhance the predictability of future policy actions does not properly characterize the thinking of the government or most of its advisers. ${ }^{68}$

According to our interpretation the government recognized that it must deal with strategic behavior by agents in the private sector. Without denying the scope in principle for stabilization policy, it concluded that the private sector, and especially organized labor, would respond to activist stabilization rules in such a way that both runaway inflation and ever growing fiscal imbalances would result.

To borrow the language of game theory, the 1944 White Paper on unemployment acknowledged that the objectives of full employment, price stability, and productivity growth could only be achieved as a cooperative solution to the government-union-management "game," given the institutional structure of labor markets. But the Thatcher government appears to have concluded, first, that the unions have progressively exploited the government's commitment to maintain full employment by reneging on their sometimes explicit but mostly implicit part of the social contract to exercise wage restraint and to facilitate the introduction of new technology and improved working practices. Second, the government seems to have concluded that no commitment by the unions to support a cooperative equilibrium would be credible.

Stabilization policy, in this view, had thus degenerated into accommodation of wage and price pressures, underwriting of increasingly uncompetitive firms and industries through domestic demand pressure,

68. For an example of the new classical macroeconomics, see the memorandum by Minford in Memoranda on Monetary Policy. 
and provision of direct subsidies of various kinds. Furthermore, incomes policies-attempts to enforce certain aspects of the cooperative solution-were bound to be unsuccessful because they supplied neither sufficient sticks nor carrots, and because of the cumulative distortions they introduced in the resource allocation mechanism and the relative earnings structure.

The government's response to the perceived failure of the cooperative solution, and the danger that the authorities would end up passively following organized labor's leader, was to take the drastic step of discarding not just passive accommodation but the entire notion of stabilization. Instead, it adopted a "credible threat" strategy by announcing fixed, open-loop paths for monetary and fiscal instruments and giving the unions a credible commitment: "you break it, you own it."

Such a strategy represented a major departure from past practice by postwar governments of any political bent. But the credibility of the implicit threat to those settling wages and prices in the private sector was not enhanced by the initial 25 percent increase in public sector earnings nor by the wayward behavior of the chosen monetary target. Any skepticism about the seriousness of the government's intentions has, however, been dissolved by its willingness to tolerate or even encourage levels of unemployment that would in the past have caused the authorities to ease monetary policy, engineer a fiscal stimulus, or both. This, rather than the achievement of its intermediate targets (which in the case of $£ \mathrm{M} 3$ was significantly overshot) has established the credibility of the government's anti-inflation, nonaccommodating policies.

One of the undoubted costs of this achievement has been that the government has rejected the idea of managing the economy at a time when the United Kingdom, in common with many other Western countries, is in a prolonged slump. Moreover, to the extent that the Thatcher experiment is found worthy of emulation overseas, the likelihood of any concerted, deliberate expansion is reduced, thus ensuring that the Western world will be left increasingly to those natural forces whose failure to ensure high employment led to the birth of Keynesian macroeconomics in the first place.

If, nevertheless, credibility has by now been achieved, will further reductions in the rate of inflation be less costly than the earlier ones that took place before the investment in credibility began to yield a return? The answer is probably yes, but not very significantly. The credibility 
that has been achieved is a general rather than a specific credibility. The threat of nonaccommodation, as Tobin argues in his evidence presented to the Treasury Committee, is "a threat to everyone in general and noone in particular." If organized labor were unified and in control of its rank and file and its shop stewards, such a policy could pay dividends. As it is, it may still appear quite safe for relatively small groups of workers to play the traditional game without taking into account the macroeconomic constraints that the authorities have imposed on the economy as a whole. This applies both to "unwarranted" wage claims and to resistance to productivity-enhancing innovations. The combined effect of decentralized, uncoordinated union pressures (or resistance) meeting unconditional monetary and fiscal targets with a deflationary bias is likely to be a continuing recession.

The dilemma facing the authorities is a real one. How can the government achieve the benefits from conditionality, flexibility, and responsiveness in policy design without sliding into the position of simply accommodating pressures exerted by groups in the private sector, a posture from which it may be difficult to recover while retaining popularity, as both Edward Heath and James Callaghan discovered? The answer appears to lie either in credible commitments from social partners who have strategic power, or in the reduction of this power vis à vis that of the government, so that the government can then act as a dominant player. Given the authorities' unwillingness to consider cooperative solutions in the past, a policy of weakening the bargaining power of labor has provided the only means of creating the conditions for noninflationary growth. Though we would prefer the pursuit of cooperative solutions to "stagflation," with credible commitments from organized labor, the redistribution of industrial and economic power under current policies, which is still continuing, may already have proceeded to the point at which demand can be substantially expanded without adverse consequences for inflation or real labor costs.

\section{Conclusions}

The behavior of the British economy since our previous BPEA paper on the first two years of the Thatcher experiment has confirmed some of the tentative conclusions we reached in 1981. There is nothing in the behavior of inflation, unemployment, and output since 1979 to support 
the view that establishing the credibility of an anti-inflationary policy is by itself sufficient to achieve a desired reduction in inflation without appreciable costs in the form of increased unemployment and lost output even if it makes these costs lower than they would otherwise have been.

It is still too early to know the consequences for trend productivity of the government's macroeconomic and supply-side policies. Rapid growth of labor productivity since 1980 , especially in manufacturing, has taken place against a background of declining or stagnant output, and conflicting interpretations abound.

The most dramatic departure of the Thatcher administration's approach to economic policy design from that of all other postwar administrations was its decision to no longer formulate economic policy in terms of the pursuit of ultimate objectives such as employment, inflation, or output, but to focus instead on intermediate financial targets. How, if at all, these targets were to be revised in the light of changes in economic circumstances was never made explicit.

Whatever the initial intention, the MTFS has progressively become a strategy for fiscal contraction as the PSBR targets, initially said to be secondary to the monetary targets, have come to dominate the design of macroeconomic policy. ${ }^{69}$ The PSBR targets have thus far been achieved by cutting capital formation in the public sector and by imposing a large increase in the average direct plus indirect tax burden. ${ }^{70}$ Current public spending on goods and services has continued to grow in real terms. If future PSBR targets are to be met, and if the government's declared intention of reducing the tax burden is to be realized, future cuts in transfer payments (pensions, unemployment, and illness benefits) or in current exhaustive spending (health, defense, and education) appear inevitable.

A principal function of the MTFS has been, as we see it, to free the government from commitments that it believed implied passive accommodation of inflationary wage-price trends. It has served that purpose: the government's willingness to pay any price to fight inflation has been demonstrated, and inflation has been sharply reduced. It is a mistake, however, to think that continued success involves unswerving commitment to a program for intermediate targets conceived in the first few

69. There is some evidence to suggest that broad monetary targets were first introduced in 1975 at least in part with the intention of limiting the potential for fiscal expansion at fixed interest rates. See Fforde, "Setting Monetary Objectives."

70. See, for example, Economic Trends, no. 358 (August 1983), p. 16. 
months of office. The government has, as Fforde explained, preserved its anti-inflationary reputation while relaxing its monetary targets, much as Paul Volcker has done in the United States. What is now required is a similar adjustment of the fiscal targets that were not intended to be immutable in the first place. It is the credibility of results, and not of intermediate targets designed to produce them, that the prime minister should work for, as it is by these results that her performance will ultimately be judged. ${ }^{71}$

The government has achieved, albeit at a high cost, a major reduction in inflation, having significantly weakened the power of labor to achieve real wage increases in excess of the growth of productivity and to resist changes in work practices and the introduction of new technology. Now, with idle labor, capital, and managerial resources in unprecedented abundance and with a large and very contractionary structural budget surplus, the main risk is that the sustained recovery that is possible will abort through lack of effective demand. Slow growth in the world economy will limit the contribution made by external demand at a given real exchange rate, and the world recession may limit the extent to which "competitive depreciation" will be possible. Hence the growth of demand will have to be generated in large part domestically. The public sector is in a position to provide the required stimulus by bringing about a "supply-side-friendly" fiscal expansion with sufficient monetary accommodation to prevent an appreciation of the currency and a rise in short-term interest rates. ${ }^{72}$ This can be accomplished without violating the canons of fiscal sustainability and without threatening the antiinflationary gains.

Unless this expansion of demand takes place, any potential renaissance in productivity will either merely add to the dole queue or fail to materialize for lack of investment. An increase in supply potential without an increase in demand may, like faith without charity, come to nothing.

71. See Thomas Schelling, "Establishing Credibility: Strategic Considerations," American Economic Review, vol. 72 (1982), pp. 72-80; and James Tobin in Monetary Policy.

72. See, for example, Bryan Hopkin, Marcus Miller, and Brian Reddaway, "An Alternate Economic Strategy-A Message of Hope," Cambridge Journal of Economics, vol. 6 (March 1982), pp. 85-103; and Rudiger Dornbusch and others, "Macroeconomic Prospects and Policies for the European Community," CEPS Paper 1 (Brussels: Centre for European Policy Studies, April 1983); and Institute for International Economics, Promoting World Recovery: A Statement on Global Economic Strategy (Washington, D.C.: IIE, December 1982). 


\section{Comments and Discussion}

Jeffrey D. Sachs: When Willem Buiter and Marcus Miller first analyzed the Thatcher experiment at the Brookings Panel meeting in 1981, the heaviest costs of disinflation had already been borne in the United Kingdom, but few of the benefits were yet apparent. Inflation in mid1981 was about 12 percent, not far from the rate when Thatcher took office, though admittedly it was a rate far below the peak rate of more than 20 percent $(1980: 2)$ that had been reached as a result of external shocks and domestic policy mistakes. At the same time, unemployment had doubled between 1979:2 and 1981:2, to a rate of 10.4 percent. In those circumstances, there was little basis for a cost-benefit analysis of Thatcher's policies; the costs were plainly enormous, and few benefits were anywhere in sight. Thus Buiter-Miller, round 1, focused on the causes of the depression and not on its ostensible justification or positive returns.

On the surface at least, much has changed in the United Kingdom's economy since that paper was written. Thatcher partisans now find vindication in the government's macroeconomic policies in two key areas: inflation control and productivity growth. According to table 2 in the Buiter-Miller paper, the retail-price-index inflation has declined to a mere 4.6 percent in 1983:1, which if continued for a year would be Britain's best inflation performance since 1968. On the productivity front, output per worker in manufacturing grew 17.2 percent during 1980:4-1983:1, by far the fastest growth since 1973. Also, the aggregate output decline ended in 1981, and the United Kingdom's real GDP grew 1.2 percent in 1982, at a time when total output in the United States and Germany declined. Unemployment has stabilized as well, though at the astronomical rate of 12.5 percent of the labor force. 
Now, at least, it begins to make sense to compare the costs and benefits of Thatcher's macroeconomic policies, and Buiter and Miller devote a good part of their paper to that exercise. To their credit, the authors try to be exceedingly fair in their calculations, considering the issues from many points of view. But to their detriment, they are somewhat casual in their procedures. The authors do not specify or test any of their own econometric equations, though they give a summary description of many studies by other authors. I believe that more careful empirical work will show much of the gain in inflation and productivity to date is probably unsustainable if the economy returns to full employment. In a word, the gains are probably in large part the one-shot effects of a move to Depression-level unemployment rather than a sign of structural rejuvenation.

Most structural models of wages, prices, and unemployment show that changes in inflation are negatively related to both the level of unemployment and the change in unemployment. A typical reduced form is

$$
\hat{P}_{t}=\hat{P}_{t-1}-a\left(U_{t}-U_{t}^{N}\right)-b \hat{U}_{t} .
$$

According to my equation 1 , a change in inflation between time zero and $T$ can be attributed to two factors: the cumulative unemployment in excess of the natural rate between $t=1$ and $t=T$; and the rise in unemployment between zero and $T$ :

$$
\hat{P}_{T}-\hat{P}_{0}=-a \sum_{t=1}^{T}\left(U_{t}-U^{N}\right)-b\left(U_{T}-U_{0}\right)
$$

For policy purposes it is crucial to know how much of a given disinflation has come from the two parts, for only the first piece represents a sustainable gain in inflation assuming that policy would like to move the economy back to its initial level of unemployment. The "sacrifice ratio" should be calculated as $1 / a$ because that measures the cumulative unemployment (above $U^{N}$ ) that must be endured to reduce permanently the inflation rate by 1 percentage point, assuming that the economy begins and ends the adjustment path at the natural rate; that is, $U_{0}=U_{T}$ $=U^{N}$. When Buiter and Miller calculate a sacrifice ratio of $2.3(20.2$ cumulative points of unemployment since 1979 , with an 8.8 point slowdown in inflation), they implicitly assume that all of the disinflation is due to the level effect because they calculate 


$$
1 / a=-\sum_{t=1}^{T}\left(U_{t}-U^{N}\right) /\left(\hat{P}_{T}-\hat{P}_{0}\right) .
$$

This calculation makes sense only if $b \equiv 0$. When $b>0$ and $U_{T}>U_{0}$, the calculation clearly understates the true sacrifice ratio.

There is reason to believe that most of Britain's inflation gains in recent years is due to the change effect rather than the level effect. To make this point, one must look closely at the coefficients $a$ and $b$ in equation 1 to understand the sources of the rate-of-change effect. A standard derivation of this equation includes the following elements for the Phillips curve, the variable markup equation, consumer prices, and terms of trade, respectively:

$$
\begin{aligned}
\hat{W}_{t} & =\hat{P}_{C_{t-1}}-\psi\left(U_{t}-U^{N}\right) \\
\hat{P}_{t} & =\hat{W}_{t}-\theta \hat{U}_{t}+\rho \hat{P}_{t}^{R} \\
\hat{P}_{C_{t}} & =\lambda \hat{P}_{t}+(1-\lambda)\left(\hat{E}+\hat{P}_{t}^{*}\right) \\
\hat{\pi}_{t} & =\hat{P}_{t}-\hat{E}-\hat{P}_{t}^{*},
\end{aligned}
$$

where

$$
\begin{aligned}
W & =\text { hourly compensation } \\
P_{C} & =\text { consumer price index } \\
U_{t} & =\text { aggregate unemployment rate } \\
P & =\text { price of domestic output } \\
P^{R} & =\text { real price of intermediate input } \\
E & =\text { nominal exchange rate } \\
\pi_{t} & =\text { final-good terms of trade }
\end{aligned}
$$

After a bit of manipulation one finds

$$
\hat{P}_{C_{t}}=\hat{P}_{C_{t-1}}-\psi\left(U_{t}-U^{N}\right)-\theta \hat{U}_{t}-(1-\lambda) \hat{\pi}_{t}+\rho \hat{P}_{t}^{R} .
$$

Comparing my equations 1 and 4, one can see that the level effect is related to the coefficient on unemployment in the Phillips curve equation. The rate-of-change effect is tied to the markup coefficient on the price equation. That is, as output falls (or unemployment rises) profit margins are squeezed and inflation is reduced. Since profit margins expand during a recovery, this gain is temporary.

There is also a terms-of-trade or competitiveness effect on inflation. A real exchange rate appreciation $\left(\hat{\pi}_{t}>0\right)$ reduces import costs, and 
through them, the consumer price index. This effect is also of the rateof-change rather than level variety, because a terms-of-trade improvement (or "loss in competitiveness," which sounds less wholesome) tends to accompany a change in the level of money tightness and thus output, and because policy-induced real exchange rate appreciations must typically be reversed in order to return to a sustainable current account position.

Some standard models of output and inflation have $\psi>0$ and $\theta=0$, where the latter assumption is of pricing at a fixed markup over normal costs. Probably the opposite set of assumptions is better for the United Kingdom. That is, real wage growth has been largely invariant to unemployment, but profit margins have been highly sensitive to the level of unemployment. The insensitivity of real wage growth to unemployment has been documented in a variety of ways, and in a variety of studies. In a recent $B P E A$ paper I pointed out that the annual growth in real hourly compensation in the United Kingdom was the same in 197381 as in 1960-73, despite the enormous rise in unemployment between the two periods (specifically, $\hat{W}-\hat{P}_{C}$ is 3.7 percent for $1960-73 ; 3.7$ percent for 1973-79; and 3.8 percent for $1979-81) .{ }^{1}$ My econometric wage equation in that paper also showed $\psi \approx 0$. Using a slightly different framework, Grubb, Jackman, and Layard recently ranked the United Kingdom as having the greatest real wage rigidity (essentially, the lowest $\psi$ ) among nineteen OECD economies, and their econometric work also found a small and statistically insignificant value of $\psi .^{2}$ Finally, there is a long tradition in the United Kingdom, following the work of Sargan, showing that the United Kingdom's real wages rather relentlessly pursue an exponentially growing real wage target. This type of equation helps to explain the rebound in real wages in 1978 and 1979 after three years of Labour party incomes policies. The enormous burst in real wages in 1978-79 would otherwise be difficult to explain, since it occurred at extremely high rates of unemployment.

On the other hand, the capacity of high unemployment to squeeze profit margins has been well documented. The fact that the "cyclically

1. Jeffrey D. Sachs, "Real Wages and Unemployment in the OECD Countries," BPEA, 1:1983, pp. 255-89.

2. Dennis Grubb, Richard Jackman, and Richard Layard, "Wage Rigidity and Unemployment in OECD Countries," European Economic Review, vol. 21 (March-April 1983), pp. 11-39. 
adjusted labor share of value added" has risen enormously is another way of stating that the markup of prices over normal unit-labor costs has been substantially reduced since 1973, and particularly since 1979 . In my recent paper, I estimated the current squeeze of the markup to be between 19 and 25 percent of its 1965-69 level.

A regression of my reduced-form equation 4 above strongly supports the rate-of-change rather than level hypothesis. The regression equation amends 4 by adding a term, $I N C$, to pick up the effects of the Labour government incomes policies during 1974-79. The results are, with $t$ statistics in parentheses, ${ }^{3}$

$$
\begin{aligned}
\hat{P}_{C_{t}}= & 1.5+0.89 \hat{P}_{C_{t-1}}-1.29 U_{t}+1.19 U_{t-1} \\
& (2.13)(12.25) \quad(-2.97) \quad(2.28) \\
& +0.78 P \hat{R} M_{t}-3.78 I N C_{t}-0.16 \hat{\pi}_{t-1} \\
& (4.01) \quad(-3.95) \quad(-2.00) \\
\bar{R}^{2}= & 0.91, \text { Durbin-Watson }=2.07, \hat{\rho}=-0.53(-2.04) .
\end{aligned}
$$

or

$$
\begin{aligned}
& \hat{P}_{C_{t}}-\hat{P}_{C_{t-1}}= 1.07-1.45 U_{t}+1.24 U_{t-1} \\
&(1.55)(-3.27) \quad(2.24) \\
&+0.67 P \hat{R} M_{t}-4.26 I N C_{t}-0.16 \hat{\pi}_{t-1} \\
&(3.50) \quad(-4.44) \quad(-1.93) \\
& \bar{R}^{2}=0.82, \text { Durbin-Watson }=2.17, \hat{\rho}=-0.53(-2.17) .
\end{aligned}
$$

In equation $5 \mathrm{a}$, the level effect is -0.10 , that is, $-1.29+1.19$, while the rate-of-change effect is -1.19 , or twelve times as large. In equation $5 \mathrm{~b}$, which imposes a unit coefficient on lagged inflation as in 1 above, the level effect is -0.21 , or $-1.45+1.24$, compared with a rate-of-change effect of -1.24 , or six times as large. According to $5 b$, the rise in unemployment between 1979 and 1982 (6.9 percentage points) accounts for an 8.9 percentage point drop in inflation, while the terms-of-trade

3. The terms of trade for final goods in the United Kingdom are expressed as $\pi_{t}$ and are measured as the United Kingdom's wholesale price index relative to a weightedaverage wholesale price index of the industrial economies (expressed in pounds sterling); $P R M$ is the real price of imported intermediate inputs for the industrial economies as a whole, measured as the unit value of imports relative to the unit value of exports; INC is a dummy variable for incomes policies, equal to 1 in $1974,-1$ in $1976-77,1$ in 1978-79, and zero elsewhere. All data except INC are from the International Monetary Fund, International Financial Statistics. 
improvement of 27.7 percent between 1978 and 1981 explains another 4.4 percent fall in inflation. (Note that I consider $\pi_{t}$ in 1978 and 1981, since $\hat{\pi}_{t}$ in $5 \mathrm{a}$ is entered with a lag.) Put more graphically, according to $5 \mathrm{a}$ and $5 \mathrm{~b}$, a return to unemployment of a "mere" 6 percent from the current 12.5 percent would add about 8 percentage points to the current inflation rate!

This basic view that the underlying gains have been far less than the apparent gains is also supported by a wide range of forecasts by the government, the Organization for Economic Cooperation and Development, and private analysts. The OECD, for example, has recently forecast that inflation and unemployment in the United Kingdom will remain unchanged from 1983 to 1984 (at 6.0 and 12.5 percent, respectively), even though the unemployment rate is far above its historical average. Such a forecast simply reflects the view that rising unemployment, and not merely high unemployment, stands behind the recent gains.

Turning very briefly to productivity, I note that the recent productivity gains seem to have the same reversible character as the inflation gains. As I pointed out in my last $B P E A$ article, an economic downturn perceived to be permanent should raise measured productivity, as leastefficient firms and workers are booted out of the productivity data. The standard, and contrary, notion that productivity is procyclical results from the fact that until recent years, economic downturns were thought to be transient affairs, giving strong incentive to firms to hoard labor in the cyclical trough. Prime Minister Thatcher's main accomplishment in this regard seems to have been to convince firms that high unemployment and slow growth will be present for the long haul.

The British productivity "miracle" has been replicated in several other high-unemployment countries in the OECD. Belgian productivity growth in manufacturing ranks second only to Japan's during 1973-81 (among the largest eleven OECD economies), in the period when Belgian unemployment rose from 2.8 percent in 1973 to 14.8 percent in 1983. Similarly, in the Netherlands, with 15.5 percent unemployment, there has also been a productivity boom relative to the other OECD countries.

To the extent that labor-shedding in least-efficient firms explains the current surge in the United Kingdom's productivity, it is hard to see how the productivity boom could be sustained if the economy were to return to full employment. The laid-off workers would, at best, have to return 
to the same plant and equipment from which they came. In fact, the Thatcher depression has done much to restrict the growth of that industrial capacity in the past two years, to the point at which the OECD has recently concluded that the United Kingdom's capital stock in manufacturing has actually declined 1.7 percent since $1980 .{ }^{4}$

I do not want to pretend that doubts do not remain about future performance of the United Kingdom. Perhaps Thatcher will yet succeed in changing union and management attitudes and thus contribute to greater efficiency and growth. (In technical jargon, the inflation equations may not stand up to the Lucas critique.) My point is rather that such beneficent effects are not really yet in sight and certainly do not follow from the observed gains in inflation and productivity to date. If such attitudes had been changed, manufacturing real wages would not now be over 20 percent above a full-employment level, and the productivity miracle would have come with rising rather than falling employment. A defense of the policies requires a showing that economic behavior has changed, not just that inflation and productivity growth look good at 12 percent unemployment.

William H. Branson: This second installment of Buiter and Miller on the Thatcher experiment provides a thorough and interesting description of the facts and exposes several important ambiguities in the interpretation of exactly what the experiment was. Why has sterling been so strong? Was money really tight? Does the "wage gap" reflect real wage rigidity? Most interesting is the suggestion that, perhaps unintentionally, the Thatcher government achieved a deep recession and disinflation by application of standard Keynesian fiscal policy. The government thought that to control money growth the public sector borrowing requirement had to be reduced, so the budget was tightened. This fiscal squeeze produced a recession, but no control over money growth. This looks like a case of misapplication of a standard financial program of the International Monetary Fund for a developing country, where budget deficits are automatically monetized. This surely is not the case in the United Kingdom.

The paper is especially interesting because it provides tempting

4. Organization for Economic Cooperation and Development, OECD Economic Surveys: United Kingdom (Paris: OECD, February 1983), p. 43. 
puzzles that lead readers to wonder whether they can come up with a reasonable model that explains these results. In this discussion I provide one or two such explanations. I begin with the problem of why has sterling been so strong. I then shift the focus to the domestic economy of the United Kingdom, characterize the stance of policy (was fiscal or monetary policy tight or loose?), and interpret the relation between unemployment and the wage gap. I finish with a brief evaluation of policy.

Sterling has gone through a period of unusual appreciation, which has put a severe profit squeeze on the tradable goods sector. The facts were summarized in the first BPEA paper on the Thatcher government by Buiter and Miller, and in table 3 here. Before proceeding, I should note that while the exchange rate, $E$, and competitiveness, $C$, are defined in the text in the usual way as home currency per unit of foreign exchange, their inverses are shown in the tables. And the lowercase $e$ and $c$ in the text are the natural logarithms of $E$ and $C$. The nominal effective sterling exchange rate appreciated fairly steadily from $82.4(1975=100)$ in 1979: 1 to 101.8 in $1981: 1$, and then fell to 80.5 by $1983: 1$. The latter observation is in table 3 . Although the nominal rate went through a full cycle, the rate of inflation in the United Kingdom was well above that of the rest of the OECD, so the real exchange rate, defined with unit-labor costs, rose from 99.5 in 1979:1 to 155.6 in 1981:1, and declined only to 143.2 by $1982: 3$. This amounts to a loss in competitiveness of nearly 50 percent!

Buiter and Miller make more of a puzzle of this loss of competitiveness, or "misalignment," of sterling than is necessary. They present an arbitrage condition for the log of the nominal effective exchange rate, $e(t)$, in equation 1 . Expected inflation and real interest rates do not play a role in this equation. These are introduced in equation 2 for the real effective exchange rate, $c(t)$. This equation tells us that a large fall in $c$ (its inverse is shown in table 3 ) should result from the expected real rate of interest in the United Kingdom being higher than the "world" expected real rate. In table 4 the reverse was true for ex post real interest rates until the end of 1981 . This contradiction leads the authors to despair, reflecting their "inability to account satisfactorily for much of the misalignment of the pound sterling." I think one can go a little further than this.

One can relax two key assumptions in the use of table 4 . The analysis 
Table 1. Changes in the Nominal Effective Pound Sterling Exchange Rate

\begin{tabular}{|c|c|c|c|c|c|c|}
\hline \multirow[b]{3}{*}{ Year } & \multirow{3}{*}{$\begin{array}{c}\text { Inflation } \\
\text { differ- } \\
\text { ential } \\
\text { (percent) }^{\mathrm{a}}\end{array}$} & \multicolumn{2}{|c|}{$\begin{array}{c}\text { Equilibrium effective } \\
\text { nominal rate }\end{array}$} & \multirow{3}{*}{$\begin{array}{c}\text { Anticipated } \\
\text { interest } \\
\text { integral } \\
\text { (percent) } \\
\end{array}$} & \multirow{2}{*}{\multicolumn{2}{|c|}{$\begin{array}{l}\text { Nominal effective } \\
\text { rate }(1978=100)\end{array}$}} \\
\hline & & Change & Level & & & \\
\hline & & (percent) & $(1978=100)$ & & Predicted $^{\mathrm{d}}$ & Actuale \\
\hline 1978 & 3.6 & . & 100.0 & . & 100.0 & 100.0 \\
\hline 1979 & 3.7 & 3.6 & 103.6 & -14.6 & 89.0 & 93.1 \\
\hline 1980 & 6.0 & 3.7 & 107.4 & -7.7 & 99.7 & 85.0 \\
\hline 1981 & 0.1 & 6.0 & 113.8 & -5.1 & 108.7 & 85.3 \\
\hline 1982 & 1.3 & 0.1 & 113.9 & -1.9 & 112.0 & 89.6 \\
\hline
\end{tabular}

Source: Author's calculations.

a. United Kingdom less world. The inflation differential is the GDP deflator from table 2 in the Buiter-Miller paper less the OECD inflation rate from National Institute Economic Review, no. 104 (May 1983).

b. The equilibrium nominal effective rate is assumed to follow the realized inflation differential.

c. The interest differential is the world nominal interest rate as calculated by the authors less the bank rate from their table 2. The differential for four years is assumed to be anticipated, with a zero expected differential after 1982 . The integral is expressed as $\Sigma\left(r^{*}-r\right)$.

d. The predicted nominal rate is the sum of the third and fourth columns.

e. The actual nominal effective rate is the inverse of the sterling effective exchange rate from table 3 , indexed to $1978=100$.

assumes that actual inflation in the United Kingdom was anticipated. This could hardly have been the case for the inflationary explosion of 1979-80 after the Thatcher government came to power. The analysis also assumes that the expected interest differential shifted suddenly and fully in late 1979. Alternative assumptions would recognize that the market should have expected a program of future monetary tightness, and expected it with a degree of uncertainty.

To see the effect of assuming that the inflationary outburst was unanticipated, one can separate the real expected interest rate terms in equation 2 into their nominal and expected inflation components and set the expected inflation differential equal to zero. This assumes that the expected inflation in the United Kingdom was the average for the OECD. Now, because that country's nominal rates were higher than world nominal rates, at least the sign of the effect on competitiveness is right.

The magnitude of the appreciation can be checked for consistency with the assumption that the inflationary explosion was unanticipated by focusing on equation 1 and assuming that the perceived equilibrium nominal rate followed the actual relative price path. The calculation is shown in my table 1 above. The third column gives the movement in the equilibrium nominal effective rate $(1978=100)$ based on this assumption. The fourth column presents the cumulative forward nominal interest differential on the assumption that the four years from 1979 to 1982 were 
correctly anticipated, and that the expected differential after 1982 was zero. The expected cumulative nominal differential of 14.6 percent is near the value of 16 percent that Buiter and Miller cite in the text as being needed for the real interest differential to explain the fall in competitiveness in 1979-80. The predicted movement of the nominal effective rate from equation 1 and from the above assumptions is given in the fifth column; the actual is given in the sixth.

The predicted path of the fifth column shows a sudden drop to 89.0 in 1979 , and then a gradual movement back toward the "equilibrium" path, which itself is rising due to the inflation differential. This is the path predicted by equation 1 if the shift in interest rate expectations is certain and comes fully in 1979. The actual path in the sixth column shows a more gradual drop to 85.0 in 1980 and then a much slower rise. This would have produced the slower fall in the rate reflecting the initial uncertainty; the hesitant recovery reflected expected future tightness all along. ${ }^{1}$

So the magnitude of the initial appreciation of sterling is roughly consistent with the assumption that the inflation differential was unanticipated, and the persistence of the "misalignment" may reflect the market's continuing faith in the future tightness of monetary policy under the Thatcher policy regime. While this story may simply be an attempt to "make this approach consistent with the facts," it seems plausible and certainly fits the general outline of the Buiter-Miller analysis.

Turning now to the characterization of policy, I note that the shift to an extremely tight fiscal policy is well documented in the paper. By eliminating "built-in stabilizers" from the United Kingdom's fiscal structure, the cyclically adjusted budget changes since 1979 have increased the surplus each year, and policy has been much tighter than the OECD average.

The characterization of monetary policy is much more difficult. One can look at monetary aggregates, interest rates, or investment outcomes. As Buiter and Miller remark, the aggregates give conflicting signals. The monetary base grew very slowly, but broader aggregates generally more

1. The analysis of expected future policy is the same as that, for example, presented in W. H. Buiter and M. H. Miller, "Monetary Policy and International Competitiveness: The Problem of Adjustment," Oxford Economic Papers, vol. 33 (July 1981, supplement), pp. 143-75. 
than kept up with inflation. Ex post real interest rates were low and then negative in 1980. But if one incorporates information from the foreign exchange market and assumes that the inflation differential was unanticipated, real interest rates become higher by the amounts shown in the first column of my table 1 above. On the other hand, real private investment has been essentially flat since 1978 in the face of the GDP decline shown in Buiter and Miller's figure 1. Thus I find it difficult to take a strong position on whether money has actually been tight under the Thatcher regime.

A cautious characterization of policy, then, is that fiscal policy was very tight, and monetary policy was more or less neutral, with a wide range of uncertainty around the latter judgment. The recession was surely due to fiscal policy interacting with a deep inventory cycle. The important insight from this paper, and the paper they cite by John Fforde, is that the shift to tight fiscal policy was justified by the asserted need to slow money growth. This view was probably reinforced by the International Monetary Fund mission that preceded the election of the Conservative government. But in fact the relation between the budget and money growth is very loose and money continuously overshot the target paths. The ironic result is the application of a very Keynesian antiinflation policy in the name of monetarism.

A view of the relation between the "wage gap" - the excess of the cumulation of real wages over labor productivity growth-and unemployment is important for policy. Buiter and Miller show in their table 15 a small real wage gap from 1978 to 1981 in the entire economy less oil, and a gap of about 10 percent from 1978 to 1981 in manufacturing. These estimates are smaller than the previous ones of Sachs but larger than those of Dornbusch and others for the European Commission. ${ }^{2}$

The wage gap of 10 percent can be interpreted as an exogenous increase in the real wage, generating "classical" unemployment of around 8 percent or 600,000 from 1979 to the end of 1982 in manufacturing, using an elasticity of substitution of 0.8 . This could give an increase in total unemployment of approximately 2.5 percentage points since 1978 . This interpretation could be used to support a contention that the

2. Jeffrey D. Sachs, "Real Wages and Unemployment in the OECD Countries," $B P E A, 1: 1983$, pp. 255-89; and Rudiger Dornbusch and others, "Macroeconomic Prospects and Policies for the European Community," CEPS Paper 1 (Brussels: Centre for European Policy Studies, April 1983). 
"natural" rate of unemployment in the United Kingdom has risen to 8 or 9 percent.

An alternative interpretation, provided by Robert Gordon in his exposition of a "textbook" model in his comment on Sachs's 1983 BPEA paper, would impute the correlation of the wage gap and unemployment to demand fluctuations with a sticky nominal wage. As demand falls, unemployment rises along with the real product wage. The appreciation of sterling after 1978 would strengthen this relation by reducing the price level. According to this interpretation, the unemployment is "Keynesian" and can be treated by demand expansion.

The choice between these alternative interpretations depends on whether the real wage or the nominal wage is sticky downward in the United Kingdom. My paper with Julio Rotemberg, and the papers by Sachs, and by Grubb, Layard, and Jackman, provide weak support for the sticky real wage model for the United Kingdom. ${ }^{3}$ So I can agree with the cautious conclusion of Buiter and Miller that a "margin" of classical unemployment exists that would be hard to eliminate by demand expansion. But if classical unemployment is the margin, demand expansion will reduce the inframarginal Keynesian unemployment.

Finally, I turn to the evaluation of policy. Here I think it is important to separate the positive question of whether the analysis was wrong from the normative question of whether we agree with the Thatcher government's weights on inflation reduction versus unemployment. Buiter and Miller note that the "sacrifice ratio" of cumulative unemployment to inflation reduction was 2.3 until the end of 1982 . In table 13 the Treasury's estimate of the sacrifice ratio is reported as being 2.5 , which seems to have been approximately correct. The quoted monetarists were way off in their estimate, but they are not the government. So it is hard to fault the analysis here. The government was probably surprised by the depth of the recession. The March 1980 forecast of 1981-82 unemployment was 700 million low. This was corrected in the March 1981 forecast, and the outcome has been as forecasted since. Although the government was surprised in 1981, it simply adjusted the forecast upward and proceeded.

3. William H. Branson and Julio J. Rotemberg, "International Adjustment with Wage Rigidity," European Economic Review, vol. 13 (May 1980), pp. 309-32; Sachs, "Real Wages and Unemployment"; and Dennis Grubb, Richard Jackman, and Richard Layard, “Wage Rigidity and Unemployment in OECD Countries,"' European Economic Review, vol. 21 (March-April 1983), pp. 11-39. 
So although the analysis seems correct except for one surprise, the lack of policy response to the unexpectedly high unemployment reflects the low weight given to unemployment by the policymakers. On this point I join Buiter and Miller in objecting to the Thatcher government's apparent indifference to unemployment and sole targeting of inflation.

The government has confused the policy debate in the United Kingdom by proclaiming its adherence to monetarism and its intention to control money growth while pursuing a contractionary Keynesian policy. The confusion has probably been the source of the appreciation of sterling that has squeezed manufacturing profits severely. Clarity about policy might have prevented this.

Refusal to expand demand seems to be based on the overly strong assumption that all the unemployment increase since 1978 is classical. I think that, as in the United States, now that inflation has been greatly reduced, demand should be expanded. Uncertainty about the division of unemployment between classical and Keynesian suggests packaging demand expansion with some give on real wages to ensure that the result is a reduction of unemployment.

\section{General Discussion}

Stanley Fischer emphasized that Thatcher's policies should be viewed as a determined attempt to change the policy regime. Much of recent macroeconomic theory predicts that such a change would have caused shifts of coefficients in economic models estimated from the pre-Thatcher period. Fischer urged the authors to perform econometric studies explicitly testing for such coefficient shifts. Furthermore, he suggested it was inappropriate to draw inferences from relations such as the inflation equations that are discussed unless the equations could be shown to be unaffected by the regime change. He also suggested that the Thatcher strategy may have been the best one available because incomes policies had been discredited after the last Labour governments had tried to use them. Christopher Sims found the authors' measures of monetary policy stance less satisfactory than their measures of fiscal policy stance. In particular, he believed that the characterization of monetary policy by reference to the behavior of aggregates relative to their preannounced target paths was inadequate as a measure of "tightness." From the level of real interest rates and the exchange rate, Sims concluded that 
the tight monetary policy as well as tight fiscal policy were responsible for the length and depth of the recession in the United Kingdom.

Sims also reasoned that, if the measures of fiscal policy for the United States were adjusted for inflation in the same way Buiter and Miller had done for the United Kingdom, they would show that U.S. fiscal policy tightened in the first years of the 1980s. The U.S. recession would then be seen as a product of tight fiscal and monetary policies, at least in its early stages, and the contrast between the experience of the United Kingdom and that of the United States would be less marked than the authors suggest. Benjamin Friedman agreed and pointed out that, on a full-employment basis, even before inflation adjustment the U.S. federal budget showed very small deficits in 1980 and 1982 and was actually in surplus in 1981.

Several participants disagreed with Jeffrey Sachs's analysis that expansionary policies under the present circumstances in the United Kingdom would mainly reignite the wage-price spiral that the deep recession had stopped. James Tobin reasoned that the degree of real wage rigidity is likely to be inversely related to the unemployment rate, so that real wages could decline in present circumstances even if expansion resumed. Robert J. Gordon attributed the small effect estimated for the level of unemployment in Sachs's equation to the maintained hypothesis that the natural rate of unemployment has been constant throughout the period. He believed that this assumption biased downward the estimated effect of the level of unemployment on real and money wages because both the unemployment rate and the inflation rate rose in 1973-76. Gordon reported that he had found a large effect from the level of unemployment on British price behavior when he allowed the natural rate to shift to reflect structural changes such as a more generous social security net. Marcus Miller replied that there was no evidence of structural changes of the sort that would suggest large increases had occurred in the natural rate. Rather, a large rise in the natural rate was often inferred by some researchers as the simplest way to explain the concurrent rise in inflation and unemployment in the context of their models. 